\title{
DE AGONE CHRISTIANO. \\ A project of Christian life in contrast with Manichaeism
}

\author{
Alexander, PALLIPARAmbil JosePh
}

\section{ABBREVIATIONS}

\section{General}

ACW Ancient Christian Writers

AugLex Augustinus-Lexikon

BAC Biblioteca de Autores Cristianos

CMC Codex Manichaicus Coloniensis

CSEL Corpus Scriptorum Ecclesiasticorum Latinorum

DAC Dizionario d'antichità classiche

FC The Fathers of the Church

JThs Journal of Theological Studies

NBA Nuova Biblioteca Agostiniana

NDPAC Nuovo Dizionario Patristico e di Antichità Cristiane

NHMS Nag Hammadi and Manichaean Studies

NPNF A Select Library of the Nicene and Post-Nicene Fathers of the Christian Church

PL Patrologia Latina

NRSV The Holy Bible, New Revised Standard Edition

SCh Sources Chrétiennes

SEA Studia Ephemeridis Augustininanum

SVF Stoicorum Veterum Fragmenta

TDNT Theological Dictionary of the New Testament

TP Collana $<<$ Testi Patristici $>>$

WSA The Works of St. Augustine, A Translation for the $21^{\text {st }}$ Century 


\section{A. PALLIPARAMBIL JOSEPH}

\section{Works of Saint Augustine}

c. Adim. Contra Adimantum Manichei discipulum

agon. De agone christiano

cat. rud. De catechizandis rudibus

civ. De civitate Dei

conf. Confessiones

duab. an. De duabus animabus

En. in ps. Enarrationes in Psalmos

ep. Epistulae

epist. fund." Epistula fundamenti

c. ep. Man. Contra epistulam Manichaei quam vocant fundamenti

c. Faust. Contra Faustum Manicheum

c. Fel. Contra Felicem Manicheum

f. et symb. De fide et symbolo

c. Fort. Acta contra Fortunatum Manicheum

haer. De haeresibus

mor. De moribus ecclesiae catholicae et de moribus Manichaeorum,

nat. b. De natura boni.

retr. Retractationes

c. Sec. Contra Secundinum Manicheum

Sec. Secundini epistula

s. Sermones

simpl. Ad Simplicianum

vera rel. De vera religione

util. cred. De utilitate credendi

*For the abbreviations, we follow Karl Heinz Chelius, Augustinus-Lexicon, Vol. 2, pp. XI-XXX; epist. fund. from p. 1070 


\section{GENERAL INTRODUCTION}

\section{Motivation of the Research}

The notion of life as combat is not new to Christianity. Still, the fact that Augustine, one of the greatest of the Church Fathers has a small booklet on this topic, particularly with a striking title, De agone christiano, was something interesting! However, this appealing title does not seem to have produced much interest among the scholars. The direct studies realised were very few and were many years back. ${ }^{1}$ In more recent times, J. O. Reta who had taken up the theme of Christian agon had opted for the study of this idea in the whole of Augustinian corpus. And even then his main reference was elsewhere, ${ }^{2}$ in spite of the fact that De agone christiano was the first ever concrete elaboration of this topic by Augustine. ${ }^{3}$ This was intriguing! Besides, the apparent content of the work with a list of heresies, commentary of the creed and a discussion of the wickedness of devil did not seem to correspond to the title of the work. ${ }^{4}$ These many and varied factors were enough inspiration to enter into the core of our work in an attempt to seek a reasonable understanding for all these incongruous academic stories.

\section{The proposal of the Research}

At the first instant, De agone christiano is viewed as a simple catechetical treatise for the benefit of the newly baptised. ${ }^{6}$ But an extensive

1 The few direct articles were written by A. D'Ales and Roland-Gosselin; and they are dated to 1930 (A. D'Ales, Le "De agone christiano," in Gregorianum 11 (1930) 131-145; B. Rolan-Gosselin, Le combat chrétien selon saint Augustin, in Vie spirituelle 24 (1930) 71-94

2 Cf. J.O. Reta, El Combate Cristiano, según San Augustín, in Atti del Congresso internazionale su S. Agostino nel XVI centenario della conversione, Vol. 3, Institutum Patristicum Augustinianum, Roma 1987, 103-122. However, we have to recognise that recently L. Manca and L. Alici have made some valuable contribution to the study of this little book

3 Cf. L. Alici, 'De agone christiano' Interiorizzazione del Conflitto, in Lectio Augustini XVIII Settimana Agostiniana Pavese (2002), SEA 91, Institutum Patristicum Augustinianum, Roma, 2004, 36

4 Cf. L. Cilleruelo, Introducción, en El Combate Cristiano, en Obras de San Agustín, Tratados morales, BAC Vol. 12, Madrid, 1954, 476

5 Cf. retr. 2, 3 PL 32631

6 Cf. Ibid 
anti-heretical part within the framework of a negative-way-of-exposition of the creed and the possibility of an extensive Manichean background prompted us to search for whether there was something beyond this simple catechesis. So, we propose to make a deep study to bring out all possible connotations of this work behind its apparent simplicity. In short, it would mean an attempt to touch at least some of the transcendence of this opuscule. In other words, we want to discover the place and importance of this work for Augustine himself and for the Christians to whom it was written, that is, ultimately its role in the life of the Church of Hippo.

\section{Justification of the Proposal of Research}

Besides the academic motivations above discussed, De agone christiano is quite relevant to the life of every Christian as it envisages the Christian life as an agon. This is clear from the very intention of Augustine as he claimed that in it the very essentials of Christian life -the regula fidei and praecepta vivendi- are presented in a simple way! 6

Then as the reading and study went along, the fascinating world of Manichean dualistic religious system began to appear in the perspective. Its history of spectacular expansion and influence equally towards the East and the West were enough reasons for a just curiosity.

Again, we know that after the conversion, the life of Augustine or correctly speaking his pastoral commitment in the care of the flock was consumed mostly by the combat against three heresies: Manichaeism, Donatism and Pelagianism. This fact pulled us with the desire to study at least one of them deep enough, in order to understand a period and one of the many facets of Augustine's life. Obviously, Manichaeism was not the least important. Because, here Augustine was not opposing an error exterior to him like the Pelagianism or Donatism, rather something he himself lived in his own flesh and bones during his nine years of youthful search. ${ }^{7}$ And $D e$ agone christiano offered an appropriate occasion for this endeavour.

At the same time, the opinion of some modern authors that 'Manichaeism exercised a lasting influence on Augustine's was something that

7 Cf. conf. IV, 1, 1 PL 32, 693

8 They are J.van Oort, C.J. Brunner, P. Courcelle, etc. Cf. J.K. Coyle, St. Augustine's Manichean Legacy, in Manichaeism and Its Legacy, NHMS 69, Brill, Leiden, Boston, 2009, 326-328. However, we will limit here only to mention them and will not enter into the evaluation of their opinion as it will drag us away from our subject of study 
aroused our curiosity further. In the same line was Kevin Coyle's assertion that "to know Augustine one must know Manichaeism." Though looked a bit exaggerated, this too, once again fuelled our interest in this study.

\section{Methodology and Division of the Work}

In the course of study, we have divided our work in three chapters. The first chapter: 'Agon Prior to St. Augustine' is planned to expose the idea of agon in its various historical, cultural and religious background. This follows that our study will touch the idea of agon in the Greek world serving on its philosophical and moral systems. A close look into some representative books in the Old Testament which are in the ambit of Hellenistic Judaism will help us to understand the bridging role they had exercised in the process of evolution and introduction of this concept in the Christian context. To avoid dispersion, we will concentrate our study of the New Testament ambit only on the Pauline epistles (and pastorals) to bring out the main characteristic features of this core idea of our work. This is very appropriate, because for Augustine, the Apostle is the chief inspirer of this ideal. We would complete this survey touching the key authors of antiquity who preceded Augustine in its elaboration. This was indispensable as Augustine had two unavoidable giants in Christian African literature on this respect in the persons of Tertullian and Cyprian. The last part of this survey would cover asceticism and monasticism as the necessary conclusion where all these agonic ideas were concretised.

The second chapter will discuss properly the date, structure, literary style, addressee and scope of the work. From a methodological understanding one may think these are secondary aspects of the work compared to the content or the main theme, agon. But we will show ultimately that they are united intimately with the content in an inseparable way.

In the last chapter "De agone christiano: A Total Manichean Critique," the first section will be dedicated to the search of agon elements pertaining to the Manichean religious system. The analysis will bring us to the reality that those combat elements found present in their cosmology are translated into their life existentially. That is, the whole of Manichean life -their existence and activities (ethics) - is nothing but a life-long agon!

Besides, Manicheans boasted of their life, particularly of the strict life of the elect. They had also admirers among the rival religious groups in the

${ }^{9}$ Ibid., 328 
surroundings (i.e. Catholics and Donatists, etc.). So Augustine was forced to enter into the field and uncover the absurdity of their ascetic life and the cosmology on which it depended! We will try to explain that De agone christiano with its praecepta vivendi and regula fidei is a product of this attempt. This proposal of Christian agon, besides would present a solid alternative to the new Catholics to avoid the attractions of the Manichean agon (second section).

In the third section, besides the above fundamental critique to the Manichean agon in the form of Christian agon, we have tried to bring out other anti-Manichean elements present in our work. Particularly important is the idea of Christus medicus humilis which is the basic premise of Christian agon that the Manicheans wanted to destroy!

In the last or the fourth section of our work we have strived to highlight three features of our booklet in the form of synthesis: namely, Augustine's Pauline affinity; Augustine's pastoral care and finally the maturity feature (in terms of the concept of agon and the Manichean cosmology). In the ultimate analysis, we find that even these above features are explained perfectly in an anti-Manichean setting and therefore, we conclude that "De agone christiano is a total anti-Manichean critique".

The general conclusion will serve us to express our findings in the form of the purpose and the nature of De agone christiano. Besides we will point out some of the relevance of the work for today and its utility in the academic and ecclesial level. In the field of future research, we will make some suggestions for the further deepening of this opuscule.

\section{Limitations of the Work}

The very first limitation of our work is its character of being a dissertation for a licentiate program. That means, on the one side, the candidate is limited in his resources and preparation! On the other side, the work is limited in its allowed size and time! But we have tried our best to overcome these difficulties with a genuine hard-work of extensive reading and with a corresponding synthesis of the work done, without compromising the essentials.

Thus, it is understood, all that exists about the agon tradition, from its very origins in the Greek culture and philosophy towards its last development to reach the monastic ideals of Christianity in the late $4^{\text {th }}$ century, was a long road to cross. In spite of knowing them to a certain extent, it was impossible to include all the information our reading presented. 
Consequently, we were obliged to make a choice. And it is our hope that all the important authors and essential features are included.

In the course of study, Manichaeism seemed to be a greater challenge. Apart from the excellent introductory studies we have, ${ }^{10}$ the discovery of new texts and consequent new critical editions, ${ }^{11}$ and ever newer studies ${ }^{12}$ make this field an immense ocean of knowledge yet to be explored! The fact is that, we neither know all of Manichaeism (There are some still to be discovered but it is all the more sure that some would have irreversibly lost ${ }^{13}$ ) nor is possible to cover all those known facts in this small study! Summarising it to few pages seemed to be a Herculean task. But we are sure that all that is sufficient and necessary to illuminate the agon element of this ultimately syncretic religion is achieved to a great extent!

${ }^{10}$ F. Decret and P.de Luis Vizcaíno (F. Decret, Introduzione Generale, in Polemica con i Manichei, NBA XIII/1, Città Nuova Editrice, 1997, vii-cxv; P.de Luis Vizcaíno, Introducción General, en Escritos Antimaniqueos ( $\left.I^{\circ}\right)$, en Obras Completas de San Agustín, Vol. 30, $B A C$, Madrid, 1984), 3-168

${ }^{11}$ For example, Corpus Fontium Manichaeorum (CFM))

12 Particularly interesting are the studies in the series: Nag Hammadi and Manichaean Studies (NHMS)

13 Apart from fragments and quotations in various collections, there is no trace of the original seven works of Mani! 


\section{CHAPTER ONE}

\section{AGON: PRIOR TO SAINT AUGUSTINE}

\section{O. INTRODUCTION}

At the very outset we have to admit that it will be difficult if not impossible, in this chapter to make an exhaustive study of all the aspects of agon motif in Christian tradition before Augustine. Besides, the De agone christiano, the object of our study does not contain all the aspects of Christian agon that Augustine himself envisaged. ${ }^{1}$ So our treatment of the image will be confined to its use and reference to the context as applied to the term in our booklet. And we shall limit ourselves to give a background information of agon to our study, ${ }^{2}$ highlighting the relevant elements and giving ample space to Paul. ${ }^{3}$

\section{AGON IN GREEK TRADITION}

The Greek term $\cdot(\mathrm{f}<$ traces naturally its origin to the antique Greek language and culture; consequently we would look its original meaning there. But on the other hand, it is a term that had undergone changes both in its meaning and application in the successive centuries by virtue of its use in the ambit of ancient philosophy, Cynic-Stoic moral systems, Hellenistic Judaism and early Roman-Christian literature. So we shall make a

1 Augustine also treats the agon motif outside De agone christiano, for example, in $s$. 151; s. 156, 9; civ. 14, 9, 2 etc.

2 The argument of this chapter, in a broad sense follows three authors: V.C. Pfitzner, Paul and the Agon Motif, Traditional Athletic Imagery in the Pauline Literature, E.J. Brill, Leiden, 1967; A.von Harnack, Militia Christi, La religione Cristiana e il ceto militare nei primi tre secoli, L'Epos, Palermo, 2004; and E.E. Malone, The Monk and the Martyr, the Monk as the successor of the Martyr, The Catholic University of America Press, Washington D.C., 1950, in their respective study. We were limited otherwise because of their almost exclusive use of secondary sources in German language. However, where it was possible the original works are confirmed with direct quotation

3 This is important because Augustine relies a lot on the Pauline idea of agon. Besides, Paul is also highly used by the Manicheans, Cf. F. Decret, L'Utilisation des Épitres de Paul chez les Manichéens D'Afrique, in Essais Sur L'Église Manichéenne en Afrique du Nord et à Rome au temps de Saint Augustin, SEA 47, Institutum Patristicum Augustinianum, Roma, 1995, 57-107 
survey of how this term and imagery was used or understood in these areas above mentioned at least through their representative figures and their respective time period. We hope that this would give us a background and tool to understand and analyse the agon which Augustine proposed in "De agone christiano".

\subsection{Agon in Hellenistic Philosophical and Moral Systems}

Franco Montanari ${ }^{4}$ in his dictionary defines $\cdot(\mathrm{f}<$ to mean: meeting, council, assembly; place of meeting of gods, ships; and public games. This is attested by its use in Iliad. Extending the last reference to the public games, it would also mean the arena or field of competitions or simply the competition itself in its various forms, namely the contests and prize contests in the athletics and debate, discussion and battle in the theatre. In its verb form $\cdot(T<>$. @: "4, it also means combat against somebody and struggle. 5

In the same Hellenic culture, hence, it was not understood in a uniform manner, resulting a series of varied shades and meaning. Thus, for example in the ambit of games and athletic competitions the idea of the physical training and culture of the body was central to the term agon. The two principal subdivisions of athletics were: first, the true and proper athletics (athlos) that is, the contest or competitions and the consequent reward (athlon); the second, the gymnastics, which is the training of body through a series of exercises. ${ }^{6}$ Here, the most important values were selfassertion and rivalry. And they were not limited to the area of games and art but were present in every sphere of civil life (understood as a contest). ${ }^{7}$ In the games every citizen found it an occasion to excel oneself and gain glory and fame in the civil life. The ultimate goal of this self-assertion and rivalry was to become a hero like the epic gods, to be remembered perhaps even after death. ${ }^{8}$ Besides, the idea of agon as we found in the Greek

\footnotetext{
${ }^{4}$ Cf. F. Montanari, Vocabulario della lingua greca, (2 ${ }^{\mathrm{a}}$ ediz.), Loescher Editore, Torino, 2004, 69

5 Cf. Ibid., 69-70

6 Cf. F.A. Wright, Athletica, in Dizionario d'antichità classiche (DAC) Vol. 1, Edizione italiana, ed. M. Carpitella, Edizione Paoline, Roma, 1963, 244

${ }^{5}$ Cf. Ibid., 69-70

7 Cf. V.C. Pfitzner, 17

8 This is effectively illustrated by Marrou: "Abbagliare, essere il primo, il vincitore, prevalere, affermarsi nella competizione, sppiantare un rivale davanti ai giudici, portare a termi-
} 
games had its background the contest between the gods as had been depicted in the Homeric epics, particularly in the Iliad. Because of this the games were held in the festivals of gods and in vicinity of their sanctuaries and the victors were crowned with a wreath (corona - 6@Df $<0$ ) or palm branch cut from trees in the sacred grove. ${ }^{9}$ This sacred aspect will continue in the prolongation of the games and contests in the Roman culture in honour of gods and the emperor. ${ }^{10}$

All these agonistic ideals of Greek life were embodied in the Greek gymnasium as a centre and institution of training and education for the citizens in the subsequent years where the physical beauty particularly the nude body was exposed. ${ }^{11}$ It is important, however that gymnasia, for example like the Academy and Lyceum, also became centres of intellectual training and philosophy. These were places where important philosophers like Plato and Aristotle also taught. Still, the exaggerated importance of the sports in education and the craving for fame brought its ruin. ${ }^{12}$

Against this decay of the original spirit, the philosophers sought to discover the true meaning and purpose of the games and athletics. The Cynics and Stoics coined a new picture of the entire life of Sage as an agon, retaining the terminology of the public games. Hence the use becomes metaphoric. ${ }^{13}$ Thus, for the diatribe, 14 the exertions and self denials of the agon will be an exercise in virtue and moral struggle. 15 Hence what was judged as decay and degeneration in the concept and use of agon was criticised and corrected by the representatives of the philosophic systems

ne l'impresa, $\cdot D 4 F J, \mid "$, che lo classificherà al primo posto davanti agli uomini, davanti ai viventi, e forse davanti alla posterità: ecco perchè l'eroe vive e perchè muore", H.I. Marrou, Storia dell'educazione nell'antichità, Editrice Studium, Roma, 1966, 35-36

${ }^{9}$ Cf. F.A. Wright, Agoni, in DAC, Vol. 1, 38

10 The Christians showed opposition to the games because of their character as "pagan sacred contests", Cf. A.W.van Buren, Ludi, in DAC, Vol. 2, 515

11 Cf. F.A. Wright, Athletica, in DAC Vol. 1, 244

12 "The fame attached to the Pan-Hellenic games and the exaggerated desire to have a share in this fame led to a professionalism which, by means of its specialization and minute regulations for training and diet, destroyed the noble ideals of the games and converted athletics into a trade, in the vulgar sense of the word", V.C. Pfitzner, 23

13 Cf. A.von Harnack, 28

14 Small ethical debates of wandering philosophers (Cynics, Stoics etc.), Cf. W.D. Ross, Telete, in DAC Vol. 3, 627

15 Cf. E. Stauffer, Agon, in Theological Dictionary of the New Testament (TDNT), ed. G. Kittel, Vol. 1, WMB Eerdmans Publishing Company, Michigan, 1964, 135 
and popular religions. ${ }^{16}$ Here the common tendency was a shift from what was material and physical to a spiritual and metaphysical realm. However variations can be observed accordingly how it served to their particular systems of thought. This, we shall see briefly ahead.

The Sophists, for example demanded their disciples exertion on the intellectual plane. ${ }^{17}$ The tragedians of the fifth century $(B C)$ lashed out vehement attacks against the athletes. The wealth and good order of the polis was in no way profited by all the athletic feats of strength. It is wisdom alone which is of value to the state. ${ }^{18}$ In the same way Xenophon, expressing the idea of his master, presents Socrates as stressing the true and profitable exercise of the mind and soul (without excluding the bodily moderation) over against the exaggerated exercise of the body. ${ }^{19}$ The whole life of philosopher and his attempt to live and die as an ideal man is considered as an agon. However, here it is not purely a moral struggle as would figure in the later Cynics and Stoics. In the same vein, Plato himself reacted strongly against the spirit of competition which had reached such an exaggerated importance in his time and sought to lead the sports back to their original purpose, namely as a preparation for war. ${ }^{20}$ On the other hand, he assigned to athletic exercises their own educational value and moral worth in the development of the intellect and in the formation of character and personality. ${ }^{21}$ According to him the rational and tem-

16 Cf. V.C. Pfitzner, 23

17 For the Sophists, all training was a means to dot the spirit efficacy and power and Marrou rightly called this tendency a kind of 'cerebralism', Cf. H.I. Marrou, 92-93; see also pp. 78 and 91

18 Cf. V.C. Pfitzner, 25-25

19 "Furthermore, he himself never neglected the body, and reproved such neglect in others. Thus over-eating followed by over-exertion he disapproved. But he approved of taking as much hard exercise as is agreeable to the soul; for the habit not only insured good health, but did not hamper the care of the soul", Xenophon, Memorabilia and Oeconomicus, I, 2, 4 in Loeb classical library, Harvard University Press, Cambridge, 1953, 15 (for more details, see the section I.2.1-5)

20 Cf. H.I. Marrou, 105

21 "As for wrestling, the kind of trick introduced as part of their techniques by Antaeus or Cercyon because of their wretched obsession with winning, and the boxing devices invented by Epeius or Amycus are absolutely useless in a military encounter and do not merit the honor of being described. But if the legitimate maneuvers of regular wrestling -extricating the neck and hands and sides from entanglement-are practiced for the sake of strength and health with a vigorous desire to win and without resort to undignified postures, then they are extremely useful and we must not neglect them", Plato, Laws VII 796a, in Complete Works, Indianapolis, Cambridge, 1997, 1464 
peramental parts of the soul are to be harmonised through a mixture of arts and gymnastics. They are to be thus trained in order to manage and direct the third part of the soul, the seat of innate insatiable desires. ${ }^{22}$

Cynics also criticised the folly and degeneracy of games and athletics. This polemic had become a recurring theme of the diatribe. ${ }^{23}$ For them, purely physical exercise must first be transferred to a spiritual or mental plane, before it had any moral value. Showing contempt for the pride of athletic power, Cynics then claimed that they were the true athletes (agonists) in their struggle for virtue. ${ }^{24}$ The prize of this struggle is not a corruptible crown as in the public games, rather poverty, exile, dishonour; 25 and the antagonists of the sage are his own impulses and desire. ${ }^{26}$ It is by waging a continual battle with himself that the philosopher becomes $6 \mathrm{DX} 4 \mathrm{JJT}<$ (stronger) and turns victor in the true agon of life with its task of gaining •DgJZ, (virtue) and finally the $\mid \mathrm{L}^{*} " 4$ : @<>" (bliss). 27 Thus, it was the Cynics, followed by the Stoics who first developed a complete and unified picture of the agon of the sage. In picturing the task of philosopher as an agon against pleasure and pain, the Cynics and Stoics claimed to follow the great example set by their patron, Hercules because they considered his feats as moral struggles and not simply physical. ${ }^{28}$ Hence, the athletic achievement of agon received here a decidedly ethical interpretation.

22 Cf. J.D. Denniston, Platone, in DAC, Vol. 3, 140-141

23 Cf. W. Desmond, Cynics, Acumen, Stocksfield, 2008, 91

24 Cf. V.C. Pfitzner, 28

25 Cf. W. Desmond, 1 and 15

26 "The subject of the eighth Discourse is "The Real Athlete," and the speech was evidently delivered during Dio's period of exile. The reference to Diogenes' exile at the beginning is no accident. When the latter was represented as telling how he endured hunger, thirst, and poverty; and narrating the labours of Heracles, Dio's audience naturally thought of the speaker himself; and when Eurystheus, who tyrannized over Heracles, they thought of Domitian, who banished Dio", J.W. Cohoon, translators note, in Dio Chrysostom, Discourses VIII, Vol. 1, Harvard University Press, London, 1959, 375

27 Cf. V.C. Pfitzner, 28

28 "Neither, indeed, did men have eyes for struggles and labours of Heracles or have any interest in them, but perhaps even then they were admiring certain athletes such as Zetes, Calaïs, Peleus, and other like runners and wrestlers; and some they would admire for their beauty and others for their wealth, as, for example, Jason and Cinyras. About Pelops, too, the story ran that he had an ivory shoulder, as if there were any use in a man having a golden or ivory hand or eyes of diamond or malachite; but the kind of soul he had men did not notice. As for Heracles, they pitied him while he toiled and struggled and called him the most 'trouble-ridden,' or wretched, of men; indeed, this is why they gave the name 'troubles,' or tasks, to his labours and works, as though a laborious life were a trouble-ridden, or wretched life; 
The Stoics in turn, identified the highest happiness (eudemonia) with virtue; and it is attained by living according to the nature or logos or reason (god). ${ }^{29}$ So when one does not listen to the logos, he is considered insane and in him the passions (pathe) prevails. ${ }^{30}$ Meanwhile he who acts according to the reason (logos) triumphs over the passions and is invincible in the moral realm. ${ }^{31}$ According to them, the contest into which one enters, if he wishes to follow the Stoic way of life with its struggle against the desires and passions and against the whims of fortune which threaten to disrupt his peace of mind, is the Olympic contest of life itself. ${ }^{32}$ So the ultimate goal is the extinction of all the passions (apatheia). ${ }^{33}$ And he who has uprooted the passions, who is alien to it, obtains the perfection (telos) of the life, lives morally sane in such a way nothing can disturb him. He accepts then the fate as it comes. ${ }^{34}$ Greek agon is applied to a higher

but now that he is dead they honour him beyond all others, deify him, and say he has Hebe to wife, and all pray to him that they may not themselves be wretched - to him who in his labours suffered wretchedness exceedingly great. For them Hercules was not doing great works of physical strength but rather moral struggle", Dio Chrysostom, 392-393

29 According to their pantheistic idea, there is a practical identification between these terms!

30 Cf. V.G. Foà, Ricerche sull'etica delle scuole Ellenistiche, Università di Genova, 1976,45

31 Cf. Ibid., 46

32 "For what other master, then, do you wait as an excuse for this delay in self-reformation? You are no longer a boy, but a grown man. If, therefore, you will be negligent and slothful, and always add procrastination to procrastination, purpose to purpose, and fix day after day in which you will attend to yourself, you will insensibly continue to accomplish nothing, and, living and dying, remain of vulgar mind. This instant, then, think yourself worthy of living as a man grown up and a proficient. Let whatever appears to be the best, be to you an inviolable law. And if any instance of pain or pleasure, glory or disgrace, be set before you, remember that now is the combat, now the Olympiad comes on, nor can it be put off; and that by one failure and defeat honour may be lost - or won. Thus Socrates became perfect, improving himself by everything, following reason alone. And though you are not yet a Socrates, you ought, however, to live as one seeking to be a Socrates", Epictetus, Enchiridion 51, in The Works of Epictetus: His Discourses in Four Books, the Enchiridion, and Fragments, Thomas Nelson and Sons, New York, 1890, 2243

33 Stoicism in its antique version of Zeno was very rigid. He advocated not simply the moderation but the complete uprooting of the passions, to the point of scarifying the very personality of man. Thus for him the passion is "a bewildered running soul" (Cf. SVF, fr. 206), or "a movement of the soul contrary to the nature and aberrant to the right reason", Cf. $S V F$, fr. 205, in V.G. Foà, 46; However later Stoics had moderated this position. See, Ibid., 55 and 57

34 Cf. Ibid., 50 
degree here. Thus the sage's entire life, in every department of activity, especially his moral endeavours, are pictured as an agon.

Comparing to the athletic metaphor, the Stoics however widely employed the picture of boxer, wrestler or pancratiast. These figures are suited for expressing the necessity of persistent and unflinching struggle in the face of opposition. The picture of the wrester thus used to illustrate two major themes of the Stoic agon: firstly, every contest in life is a test of one's strength, and victory in each contest gives new strength and confidence for the next. Secondly, the sage might suffer set back at times, but he could start again his fight soon. ${ }^{35}$

Besides, the Stoic believed in self-sufficiency (autarcheia) and relied himself for the salvation. ${ }^{36}$ Hence, virtue and its possession were glory enough for him, because for him there was no god outside the reason or nature. ${ }^{37}$ Consequently he did not expect any approbation from men either.

\section{AGON IN HELLENISTIC JUDAISM}

The Hellenistic Judaism would mark a bridge in the use of agon in Christian context. So far, we have seen a general philosophical and socialcultural use of this term. But its application to a purely religious, spiritual realm as we know today should be sought in the Hellenistic Judaism. Here, it could be understood as the moral struggles and sacrifices which involved in agon; consequently the prize before the victor is ultimately beyond this life. ${ }^{38}$ Its characteristic spokesman was Philo. The same trend is also seen in some Old Testament books which are in the Hellenistic Judaic context, like IV Maccabeus, II Esdras and Testament of Job, etc.

\subsection{Philo}

Philo uses abundantly the image of agon in his works. In fact, like Stoics, he also criticises and ridicules the traditional Hellenistic image and appropriates some of their idea of the term. ${ }^{39}$ The true agon of life which alone deserves to be designated as holy is the contest for virtue in the

35 Cf. V.C. Pfitzner, 31-32

36 Cf. V.G. Foà, 50 - 51

36 Cf. K.von Fritz, Stoa, in DAC, Vol. 3, 526

38 Cf. E. Stauffer, 135

39 “... like those which are done by men in gymnastic contests, debasing the proper exercises of the body as coiners debase good money, and instead of athletes (athletai) becoming 
struggle against the passions and vices. ${ }^{40}$ The seeker of virtue is simply called athlete or agonist. However, in Philo these terms still maintain the idea of their original connotation so that any one of them in isolated instances is able to recall the familiar athletic metaphor. But there are instances where the athletic picture is metaphorically used without any explicit comparison with the games. ${ }^{41} \mathrm{He}$ also frequently uses wrestler, boxer or pancratiast images like the Stoics which are helpful to describe the need of effort and patience in the fight against passions. ${ }^{42}$ In this connection, as the life of Hercules was model of moral athlete in the CynicStoic diatribe, for Philo the Patriarchs of the Old Testament became embodiment of particular virtues and psychological dispositions. ${ }^{43}$

Nonetheless, Philo was a Jew and he wished to remain a faithful Jew. Hence, there are still differences between Philo and Stoic diatribe. This is illustrated in the dependence of the agonist on God. Because man's labour is perfected and honoured by the reward of God. 44 Thus, for Philo agon is that of piety and it is this piety which preserves him from the negativism of Stoic ethics and avoids the mechanical conception of Stoic struggle. Still for him, the victory depends on the strength or weakness of the contestants, providing the due weight to the human effort! 45

Another phenomenon which deserves close attention in Philo is his overcoming of the incompleteness of the picture of agon in Stoicism. Stoics in their agon for virtue normally avoided the idea of a prize. 46 Philo on the other hand, frequently refers to prizes and crowns which are awarded to the athletes of virtue and piety according to their particular feats. ${ }^{47}$ But the

miserable men (athlioi), for that is the name which properly belongs to them", Philo, On the contemplative life 41, in The Works of Philo, Hendrickson publishers, 1993, 702

40 "Therefore, in all these unholy contests, surrender the prizes to others; but, as for those which are really holy, study yourself to gain the crown in them", Philo, On Husbandry 113, in The Works of Philo, 184. See also $\mathrm{n}^{\circ} 119$ in the same page, "Therefore the Olympian contest is the only one that justly deserves to be called sacred; meaning by this, not that which the inhabitants of Elis celebrate, but that which is instituted for the acquisition of the divine, and Olympian, and genuine virtues...".

41 “... for what man, who has ever descended into the arena of life $(\cdot(f<J @ L$ \$(@L), has come off without a fall?", Philo, On Dreams II, 145, in The Works of Philo, 398

42 Cf. Philo, On Husbandry 114ff., in The Works of Philo, 184

43 Cf. V.C. Pfitzner, 41

44 Cf. Philo, Allegorical interpretation, I, 80, in The Works of Philo, 34

45 Cf. V.C. Pfitzner, 46

46 Cf. See end of section 2.1

47 Cf. See above, f. note 37 
decisive point is that the prize or crown is not claimed by the Athlete, rather granted by God, for it is God who rewards and crowns all toil. Besides, in Philo the ultimate goal and prize are the same: God himself and his blessings. 48

\subsection{Agon in Biblical Literature}

\subsubsection{Maccabeus}

Common to Philo, we see in IV Maccabeus too the religious dimension of agon. 49 This is explicit in the account of martyrdom of 7 brothers. ${ }^{50}$ According to Pfitzner, IV Maccabeus, like Philo clearly shows a good knowledge of Stoic philosophy but there are some tendencies of correction with respect to them. ${ }^{51}$ Thus for IV Maccabeus the passions and desires are divinely implanted in man; but at the same time it is the duty of mind or reason to govern over these emotions and inclinations. ${ }^{52}$ As God-given, they cannot be eradicated either; still reason can provide us some way to deal with them. Hence reason is the subject who checks the emotions but does not uproot them. ${ }^{53}$ This understanding, on the other hand contradicts the Stoic idea of •BV2g4" and •<"4F20F\" which are two main concepts of diatribe's moral philosophy. ${ }^{54}$

Stauffer is of the opinion that while for Stoics and Philo the struggle for virtue is agon, for the author of IV Maccabeus it is the passion of martyrs that makes the athletic contest. This comparison is all the more relevant as the torturing and execution of martyrs often took place in the

48 Cf. Philo, Allegorical interpretation, I, 80, in The Works of Philo, 34; Cf. V.C. Pfitzner, 48

49 "Reverence for God was victor and gave the crown to its own athletes. Who did not admire the athletes of the divine legislation? Who were not amazed? ...", IV Macc. 17, 15-16, (All Bible quotations from) Holy Bible, New Revised Standard Version (NRSV) with the Apocrypha, Hendrickson, Massachusetts, 1989

50 "Imitate me, brothers, he said. 'Do not leave your post in my struggle or renounce our courageous family ties. Fight for the sacred and noble battle for religion ( $\mathrm{JOH} \mid \mathrm{LFg} \$ \mathrm{~g} \backslash \mathrm{H})$ )", IV Macc. 9, 23-24a; "For this is why even the very young, by following a philosophy in accordance with the devout reason have prevailed over the most painful instruments of torture", IV Macc. 8, 1

51 Cf. V.C. Pfitzner, 57

52 Cf. IV Macc. 2, 21-22

53 Cf. Ibid. 3, 2-5

54 Cf. V.G. Foà, 50 
same arena and before the same spectators as the ( $\mathrm{L}: @<46{ }^{`} 4 \cdot\left(\ddot{a}<\mathrm{gH} \mathrm{H}^{55}\right.$ We can again detect yet another kind of parallelism of IV Maccabeus with the Cynic-Stoic diatribe and Philo. Thus while, for the latter the models of agon are Hercules and Patriarchs respectively, the author of IV Maccabeus -though following this tradition of models- would rather appropriate the recent historical contests of the Jewish martyrs and their $\mathrm{B}{ }^{\prime}<@ 4$ (sufferings/struggles) as his model. 56

This character of the struggle of the martyrs as an agon of endurance in suffering is closer to the image of the wrestler, boxer or pancratiast who suffers blows standing directly over against his opponent than the runner who strives forward towards the goal. ${ }^{57}$ Besides it is the holy agon they fought showing the antithesis against the worldly reward. Though the terms BB@: @<Z, (patience) and B $<@ \mathrm{H}$ (pain, struggle, suffering) are familiar to the picture of agon in the diatribe where the moral athlete is required to remain unmovable enduring the toils of pain or the blows of fortune, here in the account of IV Maccabeus these words acquire a new tone parallel to the new emphasis on agon as a struggle of suffering in martyrdom. Thus, victory in agon means endurance ( $\mathrm{BB} @: @<Z$, patience) of pain until death. ${ }^{58}$ The tyrant who forces to deny the divine Law is the antagonist or enemy. Thus victory over the pangs of suffering also includes victory over the godless ruler. Here virtue is not much different from endurance and piety and is the last word which really characterises the agon in IV Maccabeus. The piety is based on the Law, therefore agon becomes a struggle on behalf of the Law. And as God is the giver and upholder of this Law, the martyr is suffering on behave of God himself. Moreover, as God is the one who called them to agon, they are not free to take up or drop the struggle at their own whim like the Stoic sage. Consequently, it is God alone who grants them the reward of immortality. 59

55 Cf. E. Stauffer, 137, f. note 8.

56 Cf. V.C. Pfitzner, 59

57 "Like a noble athlete the old man, while being beaten, was victorious over his tortures", Cf. 1 V Macc. 6, 10

58 Cf. V.C. Pfitzner, 61-63

59 Cf. V.C. Pfitzner, 64; see also IV Macc.18, 23 "But the sons of Abraham with their victorious mother are gathered together into the chorus of the fathers, and have received pure and immortal souls from God". This is the final affirmation of the book and consequently the final fate of the martyrs! 


\subsubsection{Esdras}

The author of II Esdras shares the metaphorical use of agon. Hence, for him, the term could refer to man's conflict with the evil thoughts, which one has to conquer. ${ }^{60}$ The prize or crown is expected after death because though Esdras is assured of his reward, precisely it will not be shown to him until the last times. ${ }^{61}$ Besides for the author, the whole human life is an agon and it is to be fought by every man who is born on this earth. 62 Still, the martyr and the struggles undergone in the martyrdom are given higher regards in this book. 63

\subsubsection{Testament of Job $\mathbf{J b}^{64}$}

As a whole, the Testament of Job goes along with the theological outlook of Hellenistic Judaism. Its central theme is the virtue of endurance (or patience: hypomonee) based on the life of Job. This motif is highly exalted in the Testament of Job. The chief character, Job is presented as the hero of patience. ${ }^{65} \mathrm{He}$ would endure whatever Satan could bring; then the adversary finally learned that Job could not be persuaded away from patience to contempt. ${ }^{66}$ Though we don't find here a conscious search of struggling for virtue as in the Hellenistic agon or in the image of the Jewish martyr fighting until death, for Stauffer both of them seem to come together in the picture of the struggling Job described in this book. ${ }^{67} \mathrm{But}$ the important point is that we discover here a new tone for the image of agon. The battle, which it characterises, is limited to a personal combat between two combatants namely, Job and Satan. 68 This is further suppor-

60 "... Because they have striven with great effort to overcome the evil thought that was formed with them, so that it might not lead them astray from life to death", II Esd. 7,92

61 Cf. Ibid. 7, 77

62 Cf. Ibid. 7, $127 \mathrm{ff}$.

63 "These are they who have put off mortal clothing and have put on the immortal, and have confessed the name of God. Now they are being crowned and, receive palms", Ibid.2, 47, see also 2, 42-47.

64 All the citations are taken from: Testament of Job, in The Old Testament Pseudepigrapha Vol. 1, ed. J. H. Charlesworth, Darton Longman \&Todd, London, 1983.

65 "I am your father Job, fully engaged in endurance", Testament of Job, 1, 5

66 "So when all my goods were gone, Satan concluded that he was unable to provoke me to contempt", Ibid.20, 1

67 Cf. E. Stauffer, 136

68 "I am weary and I withdraw from you, even though you are flesh and I a sprit. I became like one athlete wrestling another, and one pinned the other. ... but because you 
ted in the following examples: in chapter 4, we see how God warns Job of the sufferings which Satan will inflict on him ${ }^{69}$ and in chapter 26, Job who is tempted by his wife to curse God, sees Satan lurking behind her. ${ }^{70}$ This theme of struggle between Satan and men is reflected frequently both in the NT, (Eph. 6, 1ff., etc.) and in post-NT literature. Thus Stauffer rightly opines that "literature of this kind obviously helped in large measure to fix the sense and application of agon and its derivatives in the early Christianity". 71

\section{AGON IN ST. PAUL 72}

The use of agon metaphor in the Christian literature and moral tradition in a certain way continues the tradition of Hellenistic Judaism, of course, with the necessary changes proper to the new way of life initiated in Jesus Christ. The lion-share of this usage can be traced in St. Paul with some occasional usage in Luke, Hebrews, etc. ${ }^{73}$ Therefore, while treating the concept of agon in Paul it is right to remember the opinion of Martin Dibelius who commenting on the New Testament paraenesis stated: "the content is often not specifically Christian in origin, but rather reveals traditional material adopted by the Christian writers. The Stoa, and its literary medium, the diatribe contributed much of the paraenetic material in the NT epistles". ${ }^{74}$ This is true in Paul too; thus he is not so far removed from the usage and the language of the diatribe. ${ }^{75}$ Still, a thorough analysis of the texts bring to light the exceptional changes which Paul had brought forth.

showed endurance and did not grow weary... but you conquered my wrestling tactics which I brought on you", Testament of Job 27, 2-3

69 "Thus says the Lord, If you attempt to purge the place of Satan, he will rise up against you with wrath for battle. But he will be unable to bring death upon you", Ibid. 4, 3-4

70 Cf. Ibid. 26, 6

71 E. Stauffer, 136

72 Here we make an extended study of Paul's use of the agon motif. The chief motive for this is Augustine's own use of Pauline terminology in his work, Cf. J.S. Remón, $E l$ Educador de la fe en las obras catequéticas de San Agustín, La catequesis del "De agone christiano", in Augustinus 15 (1970) 182. (Here Remón gives a list of Pauline texts which Augustine has used to expound his idea of agon)

73 See $L k .13,24 ; 22,44 ;$ Heb. 10, $32 \mathrm{ff}$.

74 As cited by V.C. Pfitzner, 82

75 Cf. H.I. Malone, 72 and 94 
Pfitzner chiefly treats the texts 1 Cor. 9, 24-27 and Phil.3, 12-14. ${ }^{76} \mathrm{He}$ considers that these texts give a sufficient idea of the agon metaphor in Paul. The imagery appears again in Gal.2, 2; 5, 7; Rom. 9, 16, and Phil. 2, 16; Phil. 1, 27-30 (FL<"28X4< • ( $\mathrm{f}<$ ), Col. 1, 29-2, 1 ( • ( $<<. g F 2 " 4 \cdot(\mathrm{f}<)$ and 4,12ff. $\left(\cdot\left(\mathrm{T}<\backslash . \mathrm{gF} 2 " 4 \mathrm{~B}{ }^{`}<@ \mathrm{H}\right)\right.$. Considered together these texts, we can find a unified idea of Pauline agon. ${ }^{77}$

At the very beginning Pfitzner warns us to guard against the error of many scholars who tried to overload exclusively in Paul's use of the metaphor a general religious-ethical concept of the agon. Besides, he completely rejects a Pauline conception of life itself as a moral agon, parallel to diatribal thought. 78

\subsection{Analysis of 1 Cor. $9,24-27$}

Pfitzner's analysis of 1 Cor. 9, 24-2779 and other passages bring the following conclusions: 80

Together with the tradition of agon previous to him as we have seen above, Paul also use the picture of runner; and common to diatribe and Philo the antithesis of prize is also found here. ${ }^{81}$ But unlike the diatribe, the chief context of the use of athletic image here is not paraenetic rather the defence of the apostleship of Paul and his missionary activity. ${ }^{82}$ Still we cannot exclude that aspect either, as the whole chapter is situated in a wider context of the problem of legitimacy of eating meat offered to idols which Paul has tried to answer through his personal behaviour in his apostolic activity. ${ }^{83}$ In this context the agon he exerts is the toil for the mission

76 While the 1 Cor. develops a picture of the athletic contest extensively in its various forms, Phil. gives the second largest complex

77 Among the many Pauline texts in the area of agon which Augustine had used (e.g. Eph. 6,12; 2 Tim. 4, 7-8, etc.), 1 Cor. 9 is very important and is used in De agone christiano 6,6

78 Cf. V.C. Pfitzner, 128-129

79 "Do you not know that in a race the runners all compete, but only one receives the prize? Run in such a way that you may win it. Athletes exercise self-control in all things; they do it to receive a perishable wreath, but we an imperishable one. So I do not run aimlessly, nor do I box as though beating the air; but I punish my body and enslave it, so that after proclaiming to others I myself should not be disqualified"

80 Cf. V.C. Pfitzner, $82-138$

81 Cf. v. $25 \mathrm{FJXn} "<@ \mathrm{H}-\mathrm{n} 2 " \mathrm{~kJ} @ \mathrm{H}$ (imperishable crown): Antithesis is evident here.

82 Cf. V.C. Pfitzner, 83

83 Cf. 1 Cor. $8,1 \mathrm{ff}$ 
entrusted to him by God, and not that of the sage who does it seeking the personal virtue and salvation. Paul's only concern is to serve the gospel as though his salvation itself depends upon this apostolic commission. ${ }^{84}$ Referring to the self control practised by Paul in $v$. 27, Stauffer opines that in these words there is no trace of ascetic mortification of the body, of self castigation carried out for its own sake, as the Hellenistic sage. Neither it assumes the importance of an independent virtue here, as in the Stoic diatribe nor does it serve a purely self-centred goal, but is the discipline of the fighter (of Gospel) who controls the body for his service to the Gospel. ${ }^{85}$ Thus for Pfitzner Paul's struggle in defending his apostleship cannot be equated with the general struggle of the believer. Related to this idea, Pfitzner brings an observation of Harnack regarding a particular aspect in Paul's description of this struggle: That is, instead of the normal technical term for the struggle of athlete and sage: $B{ }^{`}<@ \mathrm{~B} @<\mathrm{g} \tilde{\mathrm{A}}<$, he uses the term 6`В@H 6@B 4 < (1 Cor. 15, 58; 1 Thess. 3, 5, Col. 1, 29, Phil. 2, 16 etc.) to express his own strenuous missionary labours and those of others in the Christian congregation. ${ }^{86}$ Nonetheless, the restriction of personal liberty (enkrateia) is a rule that can be applied to both cases (like in the case of meat offered to idols). ${ }^{87}$

Another image, frequently used by Paul to illustrate the agon motif is that of military image. ${ }^{88}$ The most noted passage is in Ephesians 6.89

${ }^{84}$ Cf. 1 Cor. 9, 27, “... but I punish my body and enslave it, so that after proclaiming to others I myself should not be disqualified".

85 Cf. E. Stauffer, 137

$86 \mathrm{He}$ sees it as an intentional use of Paul to make such a distinction, Cf. A.von Harnack, as cited by V.C. Pfitzner, 102

87 Cf. V.C. Pfitzner, 97

88 We have for example “... I ask you also, my loyal companion, help these women, for they have struggled (FL<Z280FV $<$ ) beside me in the work of the gospel...", Phil. 4, 3; "For this I toil, striving with $(6 @ B 4 a ̈ \cdot(T<4 . `: g<@ H)$

) all the energy which he mightily inspires within me”, Col.1,29

89 "10 Finally, be strong in the Lord and in the strength of his power. 11 Put on the whole armour of God, so that you may be able to stand against the wiles of the devil. 12 For our struggle is not against enemies of blood and flesh, but against the rulers, against the authorities, against the cosmic powers of this present darkness, against the spiritual forces of evil in the heavenly places. 13 Therefore take up the whole armour of God, so that you may be able to withstand on that evil day, and having done everything, to stand firm. 14 Stand therefore, and fasten the belt of truth around your waist, and put on the breastplate of righteousness. 15 As shoes for your feet put on whatever will make you ready to proclaim the gospel of peace. 16 With all of these, take the shield of faith, with which you will be able to 
Though the text is understood in spiritual sense (v. 12), the war that waged is, nonetheless a real battle in its totality. And every Christian has to wage this battle. ${ }^{90}$ In fact the military image often accompanies and complements the athletic image. The parallelism of application leads also to the mingling of the two. Despite the difference in emphasis they almost appear interchangeable. ${ }^{91}$ A similar relationship can be seen in the previous agon literature. ${ }^{92}$ But the situation is far from simple. Pfitzner sums up the difference between Paul's use of the two images as follows: In the picture of the athlete, Paul emphasises the motif of goal for which one strives, ${ }^{93}$ in the military image, on the other hand, it is the thought of the enemy and the need to stand fast against his onslaughts that are predominated; 94 in the second case therefore, the stress is on defence, not on attack. 95

It is curious to note that Paul never calls himself a soldier, but this passage of Ephesians clearly pictures him as such. ${ }^{96}$ Besides, Paul described his co-workers as fellow-soldiers ( FLFJD"Bf JgH).$^{97}$ In the same way those who experienced prison with him are his fellow prisoners ( $F L<4$ P : • 8T J@4). ${ }^{98}$ And in the same tone, like a soldier he expresses his right of sustenance. ${ }^{99}$ All these specific words and usages confirm his use of the military metaphor.

quench all the flaming arrows of the evil one. 17 Take the helmet of salvation, and the sword of the Spirit, which is the word of God", Eph. 6, 10-18

90 Cf. A.von Harnack, 83

91 We will cite, for example 1 Cor. $9, v .24 ; v .26$

92 Cf. V.C. Pfitzner, 157

93 "12 Not that I have already obtained this or have already reached the goal; but I press on to make it my own, because Christ Jesus has made me his own.13 Beloved, I do not consider that I have made it my own; but this one thing I do: forgetting what lies behind and straining forward to what lies ahead, 14 I press on toward the goal for the prize of the heavenly call of God in Christ Jesus", Phil. 3, 12-14

94 "27 Only let your manner of life be worthy of the gospel of Christ, so that whether I come and see you or am absent, I may hear of you that you stand firm in one spirit, with one mind striving side by side for the faith of the gospel, 28 and not frightened in anything by your opponents $(\cdot<\mathrm{J} 46 \mathrm{~g} 4: \mathrm{X}<@ 4)$. This is a clear omen to them of their destruction, but of your salvation, and that from God. 29 For it has been granted to you that for the sake of Christ you should not only believe in him but also suffer for his sake, 30 engaged in the same conflict which you saw and now hear to be mine", Phil. 1,27-39

95 Cf. V.C. Pfitzner, 158

96 Cf. A.von Harnack, 84

97 Cf. Phil. 2, 25; Philem. 2

98 Cf. Rom. 16, 17; Philem. 23

99 "Who serves as a soldier at his own expense? Who plants a vineyard without eating any of its fruit? Who tends a flock without getting some of the milk?", 1 Cor. 9, 7 
To sum up Harnack opines that Paul did not speak of Christians generally as soldiers, but rather reserves the term for himself and his co-workers. The general idea goes more or less like this: the apostle or the missionary is a soldier of God. His campaign lies between the initial triumph of God in Christ (Col. 2, 15; Eph. 4, 8) and the final celebration of the victory at Parousia (1 Cor. 15, 24-28). Hence, Harnack is sure to affirm that 'Paul's words betray the sentiments of someone who is accustomed to feel himself a soldier and considers his work as a military campaign'.100

\subsubsection{Characteristics Proper to this agon in Paul}

Now let us call our attention to some of the characteristics proper to this agon in Paul:

\subsubsection{The Distinction between the Present Goal and Future Reward}

For Paul the present goal is the believers he has won. It can only be reached with the full application of the energies. ${ }^{101}$ Thus, his work for the gospel is more than the everyday faithful fulfilment of duty; it is a tense exertion, that is agon. ${ }^{102}$ But the final appraisal of his work will only be given on the day of the Lord. ${ }^{103}$ In other words, the goal is not to be confused or identified with the reward. The immediate goal is always the unhindered effectiveness of the Word (and the believers he has won).104 Only with respect to the divine approbation of the apostle's efforts towards the end, does the thought of reward appear, that is, only in connection with his faithfulness to divine commission. 105

100 Cf. A.von Harnack, 84-85

101 Cf. E. Stauffer, 137

102 “... but though we had already suffered and been shamefully treated at Philippi, as you know, we had courage in our God to declare to you the gospel of God in the face of great opposition", 1 Thess. 2, 2

103 ".... as you have understood in part, that you can be proud of us as we can be of you, on the day of the Lord Jesus", 2 Cor. 1,14

104 "I want you to know, brethren, that what has happened to me has really served to advance the gospel", Phil.1,12

105 Cf. V.C. Pfitzner, 108 


\subsubsection{The Element of Suffering in the Idea of agon}

Two key texts of our consideration are Col.1,29-2,1106 and Phil.1,2730. 107 In both cases we find a twofold nature of the agon. On the one hand, we see the suffering in the struggle for the Gospel and on the other, the suffering which result from this struggle. This idea of suffering, particularly its use in Phil. 1, 29 and 30 brings us closer to the picture of the agon of the martyrs in IV Maccabeus. ${ }^{108}$ Again, the v. 29 shows how the Philippians share now the apostle's agon for the faith; they are to be prepared to suffer (it is a sign of God's grace) for faith. It is in a situation of persecution when this suffering is emphasised; nonetheless this does not raise martyrdom to an ideal, to the status of the highest goal in the Christian life. Thus, Paul's agon shows active and passive suffering; besides, it has an element of 'on behalf' ( $L B X D)$ for his congregations. ${ }^{109}$ These three motifs reveal an extension of the agon to be included in the activity of his coworkers, and also of the members of an entire congregation under special duress. 110

\subsubsection{Life of Every Believer as a Foot Race}

In the same 1 Cor. 9,24 we find traces of Paul's description of the life of every believer as a foot race, without reference to his own mission or office. The most stressed point is this: the life of faith is a forward movement, a progression towards a final goal. Similar to the case of an athlete, effort and intention are necessary to reach this goal. Likewise to its attainment only, the self- restriction and renunciation serves (v. 27). In this regard, God rejects only the desiring and striving of the self-sufficient

106 "29 For this I toil, striving with all the energy which he mightily inspires within me. For I want you to know how greatly I strive for you, and for those at Laodicea, and for all who have not seen my face", Col. 1,29-2,1

107 "27 Only let your manner of life be worthy of the gospel of Christ, so that whether I come and see you or am absent, I may hear of you that you stand firm in one spirit, with one mind striving side by side for the faith of the gospel, 28 and not frightened in anything by your opponents. This is a clear omen to them of their destruction, but of your salvation, and that from God. 29 For it has been granted to you that for the sake of Christ you should not only believe in him but also suffer for his sake, 30 engaged in the same conflict which you saw and now hear to be mine", Phil.1, 27-30

108 Cf. V.C. Pfitzner, 112

109 Cf. E. Stauffer, 138

110 Cf. V.C. Pfitzner, 128 
man. ${ }^{111}$ A clearer picture of the Christian life of faith as a foot race also appears in Gal. 5, 7112 and Phil. 3, 12-14. ${ }^{113}$ If the athletic image is consciously chosen, it is only to illustrate the character of the life of faith as a forward advance. This progress above all, is a growth in maturity and steadfastness of faith within the life 'in Christ'. Hence, Paul is demanding a progress on a course which is already begun with the acceptance of the Gospel, which therefore necessarily includes a growth in sanctification as well. This process of sanctification follows God's act of justification.114 With these words the Christian ethics outlined by means of the picture of agon, and applied to the situation of every believer, is pictured as an ethics of steadfastness and endurance. The task of the believer is to preserve in and to live according to the call he has received in Christ. In this sense Paul's ethics and the ethics which is expressed by means of the athletic image, is above all an ethics of perseverance, not merely an 'ethics of maximum exertion' as thought by Stauffer. ${ }^{115}$

\subsubsection{Paul's Fight against the Heretics in His Apostolic Activity}

Going through the various texts ${ }^{116}$ where Paul is defending his apostolic activity, we find the hands of his opponents (who go against the true gospel; lead the new Christians to astray by their insistence on the necessity of still observing certain points of the Mosaic Law, etc.). At one point Paul was quite sure and saw the hand of Satan who was responsible for impeding his own course. 117 Thus Pfitzner says it is also likely that behind the opposing activity of the Judaizers Paul again might have seen the hands of Satan. ${ }^{118}$

Besides this opposition of Judaizers, there was still another kind of hindrance to the spread of Gospel. But it owed not simply to the heretics

111 Cf. Ibid., 134-135

112 "12 You were running well; who hindered you from obeying the truth?”, Gal. 5, 7

113 "Not that I have already obtained this or am already perfect; but I press on to make it my own, because Christ Jesus has made me his own. 13 Brethren, I do not consider that I have made it my own; but one thing I do, forgetting what lies behind and straining forward to what lies ahead, 14 I press on toward the goal for the prize of the upward call of God in Christ Jesus"

114 Cf. V.C. Pfitzner, 152

115 Cf. Ibid., 153

116 Cf. 1 Thess. 2, 14-16; Gal. 5, 7-8; Phil. 3, 2-7

117 Cf. "... because we wanted to come to you - I, Paul, again and again - but Satan hindered us", 1 Thess. 2,18

118 Cf. V.C. Pfitzner, 138 
but to some tendencies that had grown into the communities themselves (Phil. 3, 2ff.). In reaction to these, Paul regarded as nothing what his opponents considered the perfection of Law. Besides he wanted to become nothing but Christ-like in his death and suffering. ${ }^{119}$ In this, there was a paradox in Paul's claim of imperfection against the human perfection of his opponents. According to Pfitzner, perhaps Paul wanted to check the false pride of the persecuted Philippians. ${ }^{120}$ Moreover, for Paul only those who are in possession of the Spirit can be called the perfect, Jx8g4@4 (1 Cor. 2, 6). He also corrects the Judaizers' claim of perfection. Because, the perfection lies in the hands of God alone who has begun calling men in Christ Jesus (v. 15ff.). Again, the perfection, which is always spiritual perfection in Christ (vv. 9, 12 and 14), is never a present possession, (as the philosophers thought) but rather always a goal. Thus the Christian perfection exists in the imperfection and in the earnest longing for its fulfilment while running for the final goal, and is given by Christ himself in the last day. Hence, it is eschatological in nature. This eschatological character -in its foundation and fulfilment- is what distinguishes the Christian ethics from the legalistic ethics. ${ }^{121}$

\subsection{Agon in the Pastoral Letters}

There are three characteristic features of the use of the athletic-military image in the pastorals: 1 . They are applied exclusively to one who is walking in the footsteps of the apostle, who is the soldier of the Gospel. 2. Both images appear in a more established or stereotyped form (that is, they already presuppose Paul's use). 3. The context of application is the state of preacher or teacher who fights against the heresy. Thus they show a natural development of the use with regard to the earlier Pauline letters. ${ }^{122}$

Pfitzner identifies five passages for his study:123

12

119 "But whatever gain I had, I counted as loss for the sake of Christ", Phil. 3, 7

120 "9..., not having a righteousness of my own, based on law, but that which is through faith in Christ, the righteousness from God that depends on faith; 10 that I may know him and the power of his resurrection, and may share his sufferings, becoming like him in his death, 11 that if possible I may attain the resurrection from the dead. 12 Not that I have already obtained this or am already perfect; but I press on to make it my own, because Christ Jesus has made me his own"

121 Cf. V.C. Pfitzner, 163

122 Cf. Ibid., 165

123 Cf. Ibid., $165-186$ 


\subsubsection{Tim. 1, 18ff. and 2 Tim. 2, 3-6}

1 Tim. 1, 18ff. 124 make use of military image. Here Timothy is asked to continue the fight in faith against the deserters of faith and heretics. While in 2 Tim. 2, 3-6, ${ }^{125}$ within the context of a genuine mixture of both military and athletic image, there appears an important aspect of this fight: the necessity of the soldier to be free from the entanglement of the affairs of everyday life (v. 4). This is valid also for the Stoic sage, how ever, while he is accountable only to himself, the Christian solider makes it possible through his whole-hearted devotion to please the Lord (v. 6). It is a situation characterised by the struggle against heresy and the threat of suffering, as in Paul's own agon. We find here for the first time the expression miles Christi. ${ }^{126}$ However this is not applied to all Christians but primarily directed to the missionary and the leader of the community (vv. 1 and 2) and they are asked to be free from all the civil affairs in the same way as a soldier. This, in fact influenced in a decisive mode in the formation of monasticism. This also caused indirectly the idea of fuga mundi in the Christian world. 127 Another important point in this combat is that only the combatant who battle according to the orders is crowned (v. 5). Here the imagery comes from the athletic metaphor, nonetheless, from the preceding passage we know that the main idea is of the battle. Thus the battle of Christian leader has only value if he obeys the commandant, Christ the Lord. Therefore, it is much more similar to the military discipline.

In the last three passages: 1 Tim. 4, 7-10; 6, 11-12 and 2 Tim. 4, 6-8, the scope of the image seems to be widened to include the task of every believer:

124 "This charge I commit to you, Timothy, my son, in accordance with the prophetic utterances which pointed to you, that inspired by them you may wage the good warfare, 19 holding faith and a good conscience. By rejecting conscience, certain persons have made shipwreck of their faith, 20 among them Hymenaeus and Alexander, whom I have delivered to Satan that they may learn not to blaspheme"

125 "3 Share in suffering as a good soldier of Christ Jesus. 4 No soldier on service gets entangled in civilian pursuits, since his aim is to satisfy the one who enlisted him. 5 An athlete is not crowned unless he competes according to the rules. ${ }^{6}$ It is the hard-working farmer who ought to have the first share of the crops"

126 Cf. A.von Harnack, 85

127 Cf. Ibid., 86 


\subsubsection{Tim. 4, 7-10}

In 1 Tim. 4, 7-10 thereby, we see the warning against the dualist philosophies of Gnostic ring, ${ }^{128}$ which try to bring to the life of the faithful a Christianized form of Hellenistic struggle. ${ }^{129}$ These people accused Timothy and his community of laxity. Against them Timothy is to make a positive developing of his strength nourished on the words of faith. ${ }^{130}$ This will also constitute a contrasting element against the false exercises (agon) of the enemies. ${ }^{131}$

\subsubsection{Tim. 6, 11-12}

1 Tim. 6,11-12, in this same line opens another front of this struggle. It is a struggle against his opponents who crave for material things in Christian life (and in the Church). Against them, Timothy is advised to make good contest of faith in righteousness, godliness, faith, love, patience and meekness. ${ }^{132}$ These words are in effect a concise commentary on the training in godliness as described in $1 \mathrm{Tim}$. 4, 7 ff. In Gal. 5, 22, these similar Christian virtues are called the fruit of the Spirit. 133 Here faith should be understood as something, that by its very nature, demands struggle from the part of the believer. Faith is the field, or the arena in which the agon is to be contested. The entire life of faith demands a complete application of the strength and will of the believer to preserve in this faith under all circumstances, in temptation, in doubt, and even when under attack from outside. This, in turn, can be summed up as perseverance in faith and is applicable to all the believers. ${ }^{134}$

128 “...who forbid marriage and enjoin abstinence from foods which God created to be received with thanksgiving by those who believe and know the truth", 1 Tim. 4, 3. See also vv. 1 and 7

129 The tendency of self-acquired salvation and self sufficiency.

130 "If you put these instructions before the brethren, you will be a good minister of Christ Jesus, nourished on the words of the faith and of the good doctrine which you have followed", 1 Tim. 4, 6

131 Cf. V.C. Pfitzner, 172

132 Cf. 1 Tim. 6, 11

133 "But the fruit of the Spirit is love, joy, peace, patience, kindness, goodness, faithfulness”, Gal. 5, 22

134 Cf. V.C. Pfitzner, 179 


\subsubsection{Tim. 4, 6-8}

2 Tim. 4, 6-8135, meanwhile is an apostolic confession. Here Paul is looking back on his life's task, and looking forward to its approaching end with his death. In the previous verses (1-5), we have the final, precise summary of the duty of Timothy in preaching and teaching in order to oppose the heretics (vv. 2-4) and they show the necessity to remain steadfast in suffering (v.5). What is important in these words is the strong Pauline idea of calling: a calling to the life of faith and the need to give account to the Lord who has called. Here, his certainty of crown (v. 6) is not that of his achievement rather the certainty of hope in the promise of the One who has called. 136 Pfitzner, summing up his study of Pauline agon, further opines that though the description of agon of the apostle here does not include his final martyrdom, the beginnings of the martyr-terminology of the early Church can be seen here. ${ }^{137}$

\section{AGON IN CHRISTIAN TRADITION}

Once we have understood the important elements of the agon image, we shall now look how this idea was conceived in the early Christian Tradition. It can be reasonably imagined that all the previous contexts, be it Hellenism or Hellenistic Judaism or Pauline usages had their share in moulding this concept of Christian agon. To this we must add the contribution of all those writers like Justine, Origen, Tertullian and Cyprian etc. who had been converted to Christianity directly from their Pagan religious and socio-cultural backgrounds. This, on one hand would result in the application of agon image with resonances of the past. On the other hand, the imagery of army whose discipline and order as a metaphor had even many admires in the nascent religion of Christianity, ${ }^{138}$ this would therefore result in an extensive use of the military image applied to the Christian life as agon.

135 "6 For I am already on the point of being sacrificed; the time of my departure has come. ${ }^{7}$ I have fought the good fight, I have finished the race, I have kept the faith. ${ }^{8}$ Henceforth there is laid up for me the crown of righteousness, which the Lord, the righteous judge, will award to me on that Day, and not only to me but also to all who have loved his appearing"

136 Cf. V.C. Pfitzner, 183-184

137 Cf. Ibid., 184

138 A.von Harnack, 89 


\subsection{Agon: Applied to Christians, Martyrs}

The Pauline literature seems to give much inspiration in the application of the terminology of athlete to the martyrs soon. 139 Thus, E. E. Malone, citing the earliest document Epistola Ecclesiarum Viennensis et Lugdunensis ${ }^{140}$ that deals with the suffering of martyrs illustrates us how the athletic termini were widely used: the martyrs were called athletes of Christ, athletes of religion and athletes of God. ${ }^{141}$ This is repeated in other martyr stories in such a way that Malone, referring to the $5^{\text {th }}$ book of Eusebius' Historia Ecclesiastica142 is so confident to affirm: "This concept of the martyr as the athlete of Christ and as the gladiator who fights with the devil in the arena, persisted in the ancient Church for many years, for as late as at the time of Eusebius (+339) we find that author speaking of the martyrs in the same fashion". ${ }^{143}$ However this was not exclusive to the martyrs; in the early period of Christianity the persecutions were never far and each Christian was a potential martyr, so the imagery was also applied to all Christians in their struggle of persevering in the faith. We shall mention some authors in this regard:

\subsubsection{Clemente of Rome}

Among the authors of the first century, we see Clemente of Rome, writing to the community of Corinthians during the time of persecution, and consequent danger of martyrdom. ${ }^{144}$ At a time of division in community, he exhorts them to live in the model of the Roman military organization for the functioning of the Church. For Clemente, every Christian is a combatant, but each one has his role and has to battle with all the energy like in the army. We find here again the obedience to the leaders as in the Pastoral letters. Thus all are soldiers but in this model, the Christians have to obey the Presbyters. 145

139 We would cite, for example 1 Cor. 9, 24-27

140 As quoted in the Ecclesiastical History of Eusebius, Cf. E.E. Malone, 64

141 For more details of this application, See Ibid, f. note 1.

142 The fifth chapter of Eusebius' work deals with martyr stories, Cf. Eusebius, Ecclesiastical History (Books 1-5), (Chapter 5 -Introduction), The Catholic University of America Press, Washington D.C., 1953, 271-272

143 E.E. Malone, 68

144 J.A. Kleist, Introduction, in The Epistles of St. Clement of Rome and St. Ignatius of Antioch, The Newman Press, London, 1961, 3

145 'Let us, then, brethren, do soldiers' duty in downright earnest under the banner of His glorious commands. Let us observe those who are soldiering under our commanders, and 


\subsubsection{Ignatius of Antioch}

Ignatius of Antioch, in his Epistle to Polycarp writes using a rich military imagery more or less in the same vein as St. Paul in Eph. 6 applied to the life of Christians. ${ }^{146}$ The interesting point is that he is using the Latin technical military terms in his Greek letter to instruct the Christians! ${ }^{477}$ Though, there might be different opinions regarding the motive and inspiration of this usage, we can be sure that his short captivity at least indirectly and immediately contributed to the use of this terminology. 148 He also uses athletic termini applied to Polycarp calling him perfect athlete, athlete of God and noble athlete. 149

\subsubsection{Justine}

Another important representative of using the militia metaphor is Justine, who while using this agon image in the military metaphor is worried about avoiding any misunderstanding regarding the Christian reli-

see how punctually, how willingly, how submissively they execute the commands! Not all are prefects, or tribunes, or centurions, or lieutenants, and so on; but each in his own rank executes the orders of the emperor and the commanders. The great cannot exist without the small, nor can the small without the great. A certain organic unity binds all parts, and therein lies the advantage. Let us take our body. The head is nothing without the feet, and the feet are nothing without the head. The smallest organs of our body are necessary and valuable to the whole body; in fact, all parts conspire and yield the same obedience toward maintaining the whole of the body", Clemente of Rome, Epistle to the Corinthians 37, in The Epistles of St. Clement of Rome and St. Ignatius of Antioch, 32

146 "Heed the bishop, that God may heed you, too. My life is a ransom for those who are obedient to the bishop, presbyters, and deacons; and in their company may I obtain my portion! Toil together, wrestle together, run together, suffer together, rest together, rise together, since you are stewards in God's house, members of his household, and His servants. Win the approval of Him whose soldiers you are, from whom you also draw your pay. Let none of you turn deserter. Let your baptism be your armor; your faith, your helmet; your love, your spear; your patient endurance, your panoply. Your deposits should be your works, that you may receive your savings to the exact amount. To sum up: be long-suffering toward one another and gentle, as God with you. May you be my joy always!", Ignatius, To Polycarp 6, 1-2, in The Epistles of St. Clement of Rome and St. Ignatius of Antioch, 98

147 Cf. A.von Harnack, 90

148 Malone does not agree with the opinion of Harnack: 'Since Ignatius wrote this letter while in the custody of the Roman soldiers, he picked up these expressions from them and used them in his letter'. On the contrary, he proposes a prior knowledge of these termini both from the part of Ignatius and his readers! Cf. E.E. Malone, 97-98

149 Cf. Ignatius, To Polycarp, 1, 1, 96-97. "Bear the infirmities of all like a perfect athlete"; 1,2 "As God's athlete, be sober, the stake is immortality and eternal life"; 1, 3 "It is like 
gion as something violent. So Justine, writing to the emperor in his First Apology ${ }^{150}$ affirms the pacific nature of this combat and highlights its spiritual or metaphysical element. Besides this battle is constant and incessant till (to give up oneself in) death. 151

\subsubsection{Clemente of Alexandria}

Clemente of Alexandria is also quite distant from a pure military idea of Christianity. Harnack explains and understands this in the background of Marcionist controversy. 152 Clemente still serves this imagery to describe vividly the Christian life in military metaphor. ${ }^{153}$ Thus, for him this battle is deeply internal and spiritual. ${ }^{154}$ Besides, he makes a complete metaphorical analogy of the Christian athlete with that of the Hellenist athlete where the Christian athlete in his struggle against the wealth, has to undergo effort and struggle. But the substantial difference is that the Christian athlete, though is in need of his own struggle and training, the

a noble athlete to take blows and yet win the fight. For God's sake above all we must endure everything, so that God, in turn, may endure us"-

150 Cf. Justine, The First Apology 39, in The First and Second Apologies, Paulist Press, New York, 1997, 49-50

151 "And when you hear that we look for a kingdom, you uncritically suppose that we speak of a human one; whereas we speak of that with God, as appears also from the confession of their faith made by those who are charged with being Christians, although they know that death is the penalty meted out to him who so confesses. For if we looked for a human kingdom, we would deny it, that we might not be slain; and we would try to escape detection, that we might obtain the things we look for. But since we do not have our hope on the present, we do not heed our executioners since death is in any case the debt of nature", Ibid. 11,29

152 For Harnack the fathers were in an uncomfortable position here as Marcian was completely against the warrior-like figure of the God of Old Testament, Cf. A.von Harnack, 97-98

153 We have here, the examples of his Protrepticus XI, II 6, 2-4; Stromata, VII, 16, 100; Paedagogus, I, 7, 54 as cited by Cf. A.von Harnack, 95-97

154 “... ${ }^{4}$ l'altra, la più difficile persecuzione è dal dentro mandata a ciascuno dall'anima stessa dilaniata da desideri senza Dio e da piaceri variegati e da speranze vuote e da sogni destinati a perire, quando essa sconquassata dalla brama del sempre più e provocata e infiammata da amori selvaggi, come da pungoli o tafani che le stanno attaccati, si insanguina di passioni per muoversi verso attrattive spudorate e disperazione di vita e disprezzo de Dio. ${ }^{5}$ Questa è la persecuzione più pesante e più difficile, che nasce dal di dentro, che è sempre presente, che non puo essere elusa da chi ne è inseguito, giacché egli porta il nemico in se stesso, dovunque", Clemente Alessandrino, Quale ricco si salverà? 25, 4-5, Città Nuova, Roma, $1999,49-50$ 
ultimate victory depends on the Lord and not his exclusive personal effort. 155

\subsection{The agon Usage in Christian Africa}

Here we treat Tertullian and Cyprian in a separate section to highlight them as the immediate predecessors of Augustine.

\subsubsection{Tertullian}

Though Tertullian was opposed to the military service, he too used the military imagery to describe the Christian spiritual combat. It seems that his family background and upbringing had indelible mark in his thought. 156 Thus for him the Christians are the soldiers of Christ under the guidance of bishops, presbyters and deacons whose emperor is Christ. ${ }^{157}$ And following the same military imagery the heretics would be the rebels and deserters of the Church.158 The concept of the martyr as a miles Christi also appears very prominently in the works of Tertullian. ${ }^{159}$

155 “3 Ma, al modo stesso in cui vanno le cose degli atleti, per paragonare realtà piccole e caduche a realtà grandi e incorruttibili, così il ricco secondo il mondo consideri che vanno le cose sue. ${ }^{4}$ Tra gli atleti infatti l'uno, che non ha sperato di poter vincere e di ricevere la corona, non si è neppure iscritto alla gara; l'altro, che ha concepito nella sua mente questa speranza ma non ha affrontato fatiche e allenamenti e diete adeguate, è risultato senza corona ed è fallito nelle sue speranze. ${ }^{5}$ così uno, anche circondato di questo terreno rivestimento, non si escluda da solo, sin dall'inizio, dai premi del Salvatore, se è credente e vede la grandezza dell'amore che Dio ha per l'uomo, né poi speri di conseguire le corone dell'incorruttibilità, se rimane privo di allenamento e di gara, senza fatica e senza sudore. ${ }^{6}$ Si offra piuttosto all'allenatore, il Verbo, al giudice della gara, il Cristo. Cibo per lui e bevanda assegnata sia il nuovo testamento del Signore, esercizi di allenamento i comandamenti, decoro e bellezza le belle disposizioni: amore, fede, speranza, conoscenza della verità.., mitezza, misericordia, dignità, affinché quando l'ultima tromba darà il segnale della corsa e dell'uscita da qui come da uno stadio della vita, con buona coscienza, possa stare dinanzi al giudice di gara, vincitore, riconosciuto degno della patria di lassù, nella quale entra con corone e proclamazioni angeliche”, Ibid. 3, 3-6, 25-26

156 Tertullian was son of a Centurion, Cf. F. Decret, Early Christianity in North Africa, Cascade Books, Eugene, 2009, 33

157 Cf. A.von Harnack , 106

158 "Da nessuna parte si ottiene più facilmente vantaggio che nell'accampamento dei

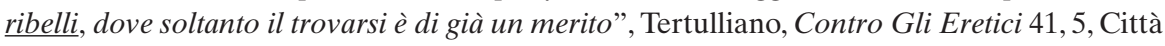
Nuova, Roma, 2002, 88

159 "We were called to the service in the army of the living God in the very moment when we gave response to the words of the sacramental oath", Tertullian, To the martyrs 3, FC, New York, 1959, 22 
For him, the prisons are the house of the devil where the martyrs have entered to trample him; 160 besides he reminds the martyrs that they are soldiers of Christ and as such they must accustom themselves to all kinds of hardships just as the professional soldiers. ${ }^{161}$ Of particular interest is the use of the term 'sacramentum'. Beyond its common meaning related to sacraments, ${ }^{162}$ Tertullian is using it in the sense of military swearing to indicate Christian's uncompromising loyalty to Christ as his soldier in baptism. 163

\subsubsection{Cyprian}

In the western Latin Church, the years after Tertullian, the sermons and exhortations are full of imagery of military service, military discipline and warfare. Harnack says it was more abundant in Cyprian than any others. ${ }^{164}$ Besides, though Cyprian died almost a century before the birth of Augustine, he was so vividly present through his writings in the daily life of Christian Africa. ${ }^{165}$

The notion of the martyr as the miles Christi is prominent in the writings of Cyprian. ${ }^{166}$ In his address to the confessors he reminds that Christ

160 " 4 Indeed, the prison is the Devil's house, too, where he keeps his household. But you have come to the prison for the very purpose of trampling upon him right in his own house. For you have engaged him in battle already outside the prison and trampled him underfoot.

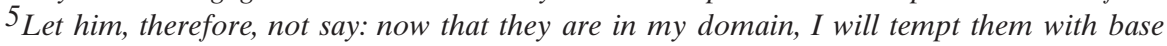
hatreds, with defections or dissensions among themselves", Ibid. 1, 4-5a, 18

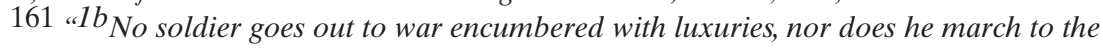
line of battle from the sleeping chamber, but from light and cramped tents where every kind of austerity, discomfort, and inconvenience is experienced. ${ }^{2}$ Even in time of peace soldiers are toughened to warfare by toils and hardships: by marching in arms, by practising swift maneuvers in the field, by digging a trench, by joining closely together to form a tortoise-shield", Ibid. 3, 1b-2a, 22

162 In this sense it means the visible sign of a spiritual reality (divine truth) which mysteriously related to the same reality, Cf. A. Grappone, Sacramento, in NDPAC, diretto da A. Di Berardino, Marietti, Milano, 2007, 4651-4654

163 "In military language, the term sacramentum was used to denote the military oath of allegiance. It is in this sense that Tertullian employs the word here, referring to the baptismal vows of the Christian”, Cf. R. Arbesmann, Introduction, f. note 1, in Tertullian, To the Martyrs, 22

164 A.von Harnack, 117

165 His writings were widely read in Christian Africa, Cf. G.W. Clarke, Introduction, in Cyprian, The Letters of St. Cyprian of Carthage (1-27), Newman Press, New York, 1984, 10-11

166 Cf. E.E. Malone, 99 
is the imperator, ${ }^{167}$ and Christians are milites Christi. ${ }^{168}$ Thus, in the years after these two great African theologians the image of the life of Christian as spiritual military service becomes very popular. The comparison becomes so narrow that for every aspect there is a simile: thus Baptism is Christian sacramentum militiae, and spiritual war, a marvellous spectacle for God and angels, the Church is the castra Dei, and heretics and schismatics are rebels and traitors. 169

\subsection{Origin}

The Greek authors we have mentioned above, like Justine and Clemente of Alexandria, Origin too completely distances himself from the earthly war. ${ }^{170}$ In the background of the Marcionist controversy of exclusion of the militaristic God of Old Testament, he will have to defend the pacific nature of the Christian concept of God interpreting the belligerent texts of the Old Testament allegorically. Thus the Christian combat would be spiritual and not "carnal" following the same way as St. Paul in Eph. 6, 12.171

But still there is another important crisis of the time: there are a lot of lukewarm Christians, and the case is not so desirable even among the clerics. So, stressing the teaching in Timothy, that the real soldiers are those who do not mix in the civil affairs, 172 he identifies them with the ascetics. Thus Harnack opines that "In the Catholic Church, Origen had been the father of the concept that ascetic (soon the monk must follow him) was the true soldier of Christ" (tr. mine). ${ }^{173}$ Further he makes a complete

167 "It is the duty of every soldier of Christ to stand by his general's orders; so much more is it fitting that you should show special diligence in your obedience to His orders, in that you have become for others a model both in valour and in the fear of the Lord", Cyprian, Letter 15, in The Letters, 91

168 "They form the bright army of the soldiers of Christ, whose steadfastness broke the fierce onslaught of persecution", Cyprian, The Lapsed, in De Lapsis and De Ecclesiae Catholicae Unitate, Oxford university Press, Oxford, 1971, 3

169 Cf. E.E. Malone, 100

170 "And though we do not become fellow-soldiers with him, even if he presses for this, yet we are fighting for him and composing a special army of piety through our intercession to God", Origen, Contra Celsum VIII 73, Cambridge University Press, Cambridge, 1965, 509

171 Cf. A.von Harnack, 100

172 "No soldier on service gets entangled in civilian pursuits, since his aim is to satisfy the one who enlisted him", 2 Tim. 2, 4

173 "Nella chiesa cattolica Origne è stato il padre del concetto che l'asceta (cui doveva presto seguire il Monaco) era il vero soldato di Cristo", A.von Harnack, 101 
description of how this battle is done by the ascetic: "He leads an incessant war against the sin, sees the demons and inflicts him a furious battle; he and only he is, then, the soldier whom Paul describes in the letter to the Ephesians. These soldiers also fight for the 'rest of the people', for the numerous weak people of every kind. These soldiers are always few; 'as it is few in the Church who can fight for the truth!'. But the band of Gideon was also small and gained the victory. The weapons of these warriors are prayer and fasting, meditations and good works, justice and devotion, modesty, chastity and abstinence. In their fight against the demons they are helped by the prayers of the deceased just" (tr. mine). ${ }^{174}$

The battle of these warriors is also directed towards heretics who negate the truth; hence, they are battling for the Church. ${ }^{175} \mathrm{He}$ also introduces another category of these combatants: "the heroes" and for him Peter and Paul are the greatest of all the heroes of Christ. ${ }^{176} \mathrm{He}$ further distinguishes two kinds of combatants: the weak and the perfect. While the weak fight against the flesh and blood, the perfect are engaged in a war against the wicked spirits under the heavens! ${ }^{177}$ There are still some interesting aspects of this battle of the Christian soldier that Origin envisages:

174 “Egli conduce un'incessante battaglia contro il peccato, vede i domoni e li configge in una lotta furibonda; lui e lui solo è dunque il soldato che Paolo descrive nella lettera agli Efesini. Questi soldati combattono anche per 'il resto del popolo', per il gran numero di deboli d'ogni sorta. Essi sono sempre poco numerosi; "Come pochi sono nella Chiesa quelli che possono combattere per la verità!' Ma anche la schiera di Gedeone era piccola e raggiunse la vittoria. Le armi di questi guerrieri sono preghiere e digiuni, meditazioni e opere buone, giustizia e devozione, mitezza, castità e astinenza. Nella loro battglia contro i demoni essi sono sostenuti dalle preghiere dei giusti defunti”, Ibid.

175 «Le sens de ces paroles, n'est-ce pas plutôt que la ville et les remparts représentent les doctrines et les raisonnements avec lesquels les philosophes impies édifient toutes les opinions sacrilèges et contraires à la loi divine qui sont en vigueur chez les païens et les barbares? Il faut mettre également au nombre des opinions sacrilèges et des villes fortifiées placées sur les montagnes, les affirmations que les hérétiques attribuent à l'écriture en les y plaçant comme sur de hautes montagnes », Origène, Homélies sur Josué 18, 3, Les Éditions du Cerf, Paris, 1960, 389

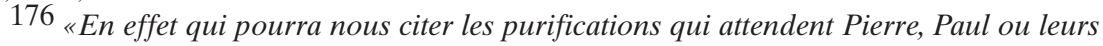
émules, eux qui se sont tant battus, qui ont détruit tant de nations barbares, abattu tant d'ennemis, pris tant de butin, remporté tant de triomphe, qui reviennent les mains rougies du massacre de ennemis, qui ont "le pied teint de sang ", et les "mains baignées dans le sang des pécheurs»? Car « ils ont tué au matin tous les pécheurs de la terre» et «banni leur image de la cité du Seigneur». Ils ont vaincu et exterminé les diverses races de démons», Origène, Homélies sur Les Nombres 25, Les Éditions du Cerf, Paris, 1951, 487-488

177 Cf. Origène, sur Josué 11, 4, 289 
The combatants either ascetic or monk, are battling under the military guidance of Jesus; this is also true in the persecutions which the Christians suffer in this world; and Christ as military head does not want any coward in his camp. ${ }^{178}$ Thus, with all these aspects of the usage of agon motif, we can reasonably think that Origin marks a connection point between its application from martyrs to monks.

\subsection{Agon and the Monk (asceticism, monasticism)}

The religious freedom brought by the Edict of Constantine would have lasting effect in this area. Until then, martyrdom was considered as the only perfection of Christian life. The short gained freedom however, had only changed the external situation but not the thinking. Thus the faithful would look for other means of perfection like the ascetic life. Consequently, all the concepts of struggle and battle that prevailed in the martyr literature would naturally pass to this new style of Christian life. But this would be only one of the reasons. There are other motives which made this application easier, namely, a) similarity between the selfimposed suffering of the monks and those imposed on the martyrs by the tyrants; b) St. Paul's use of these ideas in his letters; c) and the background of Hellenic ascetic practices. ${ }^{179}$

In a short run when the period of martyrdom passed, the image was preferentially applied to the great monastic heroes and leaders like Anthony, Macarius and Pachomius, without excluding the usage to others; neither was it exclusive to men. ${ }^{180}$ The earliest monastic writings showed that the monks were conscious of the fact that they were milites Christi in the same fashion of martyrs against devil and his angels. Thus, for St. Antony of Egypt it was a true and real fight, ${ }^{181}$ and this occurred constantly in the writings of monastic fathers. 182 Basil and John Chrysostom

178 Cf. Origin, Homilies on Judges 9, The Catholic University of America Press, Washington, D.C., 2008, $112 \mathrm{ff}$.

179 Cf. E.E. Malone, 72

180 Cf. Ibid., 76-77

181 "Living this life, let us be carefully on our guard and, as is written, with all watchfulness keep our heart. For we have enemies, powerful and crafty- the wicked demons; and it is against these that our wrestling is, as the Apostle said-not against flesh and blood, but against principalities and powers, against the rulers of the world of this darkness, against spirits of wickedness in the high place", St. Athanasius, The life of Saint Antony 21, Newman Press, New York, 1978, 38

182 Cf. E.E. Malone, 102-103 
followed the same trend of attributing to the ascetic the new model of martyrdom and the image of athlete of Christ. What was noteworthy among them was the fact that the ordinary Christians could also be called in this way and they were different from the ascetics only in degree and not in kind. ${ }^{183}$ During the time of John Cassian, these ideas seemed to be stereotyped so that he tried to explain to his readers all the background information of this life. ${ }^{184}$ What was special in him was his idea that the athlete is never let by God to be tested beyond his capacity. ${ }^{185} \mathrm{He}$ also used the military metaphor, that is, the monk was the soldier of Christ. ${ }^{186}$

The monks, on their part, were convinced that Satan was behind the temptations which they have to suffer; even the bad thoughts were his work. ${ }^{187}$ Thus to show this complete superimposition of martyr's struggle to monk Malone says: "Just as the martyrs had viewed their struggles with their persecutors as an armed conflict, so too, the monks regarded their spiritual struggles as a military engagement, in which Satan leads his armies against them. The monastery often becomes the walled fortress of the Christian soldier, and this fortress is beset on all sides by the besieging army of the evil spirits. For the soldier of Christ to leave his stronghold is fatal, because the enemy lies in ambush and will surely overcome him if he finds him thus unprotected." 188

183 Cf. Ibid., 80

184 Cf. J. Cassian, Institutions 5, 12, The Newman Press, New York, 2000, 123-124

185 "We should also by no means be unaware of the fact that not all have the same ferocity and desire, nor indeed the same courage and wickedness. With beginners and the weak only the weaker spirits are paired off in battle, and once these evil spirits have been overcome ever more robust contenders take up the fight against the athlete of Christ. For the difficulty of the struggle increases in direct proportion to a person's strength and progress. Indeed, a holy person would never be able to bear the wickedness of such great enemies and to face their onslaughts but would succumb to their cruelty and savagery were it not for the fact that Christ, the most merciful arbiter and the overseer who presides over our struggle, balances out the strength of the contestants, repels and restrains their fierce attacks, and with the trial provides a way out, so that we are able to endure", J. Cassian, Conference 7, 20, Paulist Press, New York, 1997, 260

186 " And so, it is proper for a monk always to dress like a soldier of Christ, ever ready for battle, his loins girded", J. Cassian, Institutions 1, 1, 21

187 "If, then, they see Christians in general, but monks in particular, working cheerfully and making progress, they first assail them and tempt them by continually placing stumbling blocks in their way. These stumbling blocks are evil thoughts", St. Athanasius 23, 39

188 E.E. Malone, 109 


\section{CONCLUSION}

To sum up this section we can affirm that the agon motif always distinguished an element of struggle in its various manifestations through centuries. The ideas of reward (crown) or goal, the enemy and methods or means of fighting this struggle were integral part of this agon metaphor. In the case of reward or goal it varied from the immediate ones of Hellenic games to the after-life reward in the posterior times (beginning with Hellenistic Judaism). The enemy or the opposite force varied from the limitations of the body, its passions up to devil; proportionally the methods and means of this battle are also changed. Related to the latter, the devil was also the presence (role) or absence of God in this battle.

Besides, after going through this short survey of a vast period, we consider that Paul had among them the most balanced idea of agon from a Christian point of view. ${ }^{189}$ Consequently this chapter becomes all the more important because we see the bishop of Hippo depends mostly on Paul to expound his Christian agon!190 Hence, ultimately this will help us to understand better Augustine's stand in the elaboration of agon concept with respect to the tradition he had received.

189 Pfitzner seems to favour this idea, Cf. V.C. Pfitzner, 204; 202

190 Cf. J.S. Remón, La Catequesis, 181-182 


\section{CHAPTER TWO}

\section{GENERAL ANALYSIS OF THE BOOK}

\section{O. INTRODUCTION}

In this chapter we shall occupy more than anything the "external" aspects of De agone christiano. This does not mean, however that we shall ignore completely the content; rather our primary concern and attention would be on elements that go beyond the mere content of the book. Having cleared this point, we would like to introduce the four topics which will be the subject of study in this second chapter. They are: the date, the structure, the literary style and finally the scope and addressee taken together.

\section{DATE OF DE AGONE CHRISTIANO}

The exact date of this work remains uncertain; however it is not a much contested matter. It is believed that Augustine would have composed it either in the year 396 or 397 soon after his episcopal ordination. ${ }^{1}$ The source of fixing this data comes from Augustine's own placement of De agone christiano in the second book of his "ever original work" Retractationes $^{2}$ after Ad Simplicianum and Contra epistolam Manichei quam vocant fundamenti. Again, in the Retratactiones $2,1,{ }^{3}$ referring to the two books of Ad Simplicianum, Augustine reminds us that those were the first books written by him as bishop and we know that his episcopal ordination took place at the end of the year 395. ${ }^{4}$ Therefore, De agone christiano could reasonably be written in the following years. Besides this, there are two different reasons cited by some of the scholars 5 either to

1 Cf. L. Manca, Introduzione, in Il Combattimento cristiano, NBA VII/2, Città Nuova Editrice, Roma, 2001, 51-125, 54

2 retr. 2, 3 PL 32, 631

3 "Librorum quos episcopus elaboravi primi duo sunt ad Simplicianum, Ecclesiae Mediolanensis antistitem, qui beatissimo successit Ambrosio, de diversis quaestionibus, quarum duas ex Epistola Pauli apostoli ad Romanos in primum librum contuli", retr. 2, 1 PL 32, 629

4 Cf. P. Brown, Augustine of Hippo, University of California Press, Berkeley, 2000, 66

5 These opinions are expressed by Russell and Manca in their respective introduction to the translation of De agone christiano, Cf. R.P. Russell, The Christian Combat, FC, New York, 1947, 309-310; L. Manca, 54 
favour year 396 or 397 being the possible date of composition. But these arguments seem to have not considered some elements, as we would explain below which will make us doubt their total sustainability.

Robert P. Russell points out that the reason given for favouring the year 397 is based on the reference made to the work Ad Simplicianum in the Retractationes. Here Augustine remembers Simplicianus as bishop of Milan, successor of Ambrose. ${ }^{6}$ Since he is called here bishop, it is concluded that the work must have been written at least after $4^{\text {th }}$ April 397, the date of Ambrose's death.7 However, here those above mentioned scholars did not attend to two facts! First: that in the work $\mathrm{Ad} \mathrm{Sim-}$ plicianum itself, Simplicianus is not referred to as bishop, rather pater ${ }^{8}$ So there is no evidence that at the time of the composition of the work Simplicianus being the bishop of Milan. On the other hand, it is in the Retractationes that this reference to his episcopacy is made which is obviously posterior, written when Augustine had revised his past literary legacy in 426/7. ${ }^{9}$ So this appellative could be only a fruit of Augustine's then understanding of Simplicianus' career ${ }^{10}$ and not the status of Simplicianus at the time of composition of the work!

The argument forwarded for favouring the year 396 is the so called argument of "ex silentio". ${ }^{11}$ But a careful reading of the text tells us that the intention of Augustine here is only to highlight the division among Donatists: "Nec si vere sic viverent, ut vel inter se pacem postea custodirent"12 based on the gospel passages mentioned: "In qua mensura

6 retr. 2, 1 PL 32, 629

7 Cf. M.G. Mara, Patrology (Quasten), Vol. 4, Notre Dame, IN, 1986, 150

8 "Gratissimam plane atque suavissimam interrogationum tuarum dignationem mihi, pater Simpliciane, misisti...", Simpl. (praefatio) PL 40, 101

9 Cf. A.D. Fitzgerald, Augustine Through Ages, ed. A.D. Fitzgerald, W.B. Eerdmans, Cambridge, 1999, xlxviii

10 By then we know that even Simplicianus is passed to the blessed memory. He is supposed to be dead by 400/401, Cf. S. Zincone, Simpliciano di Milano, in NDPAC, 4967

11 "The opinion which assigns the composition of this work to the year 396 is based largely upon a reference to the Donatist sect in chapter 29, 31. There Augustine points ironically to the internal schism within the sect itself, yet he fails to make any mention of the two Donatist bishops, Pretextatus and Felicianus, who had been restored to full communion even after their formal condemnation by the Donatist council of Bagua. Since this event, which took place about the beginning of 397, would have given added force to Augustine's remarks, it is argued that, had the incident already occurred, he would have made good use of it, hence, the conclusion that Augustine may have written the work, The Christian Combat, during the preceding year", R.P. Russell, 309-310

12 agon. 29, 31 PL 40, 306 
mensi fueritis, in ea remetietur vobis". ${ }^{13}$ That is, Donatus using his litigious sword of tongue caused the division of the Church, but unlike Peter, who held his sword once admonished, he did not hold his tongue even though his arguments were proved unsustainable. ${ }^{14}$ Therefore, as the Lord said, "qui enim gladio percusserit, gladio morietur,"15 he is being divided in his followers by the same sword of calumny. The reintegration of the two bishops whether Augustine knew the event or not would not have been helpful for the argument of division among them. ${ }^{16}$ Besides we know that out of the 55 bishops of Maximianist fraction only two of them were reintegrated and the division continued even after the conference at Carthage in the year $411 .{ }^{17}$ So the argument of Augustine was still valid even without mentioning the event. ${ }^{18}$ Nevertheless, for practical purpose, we will opt for the year 396 with some of the recent scholars. ${ }^{19}$

\section{STRUCTURE}

With regard to the structure of De agone christiano, we will follow closely the indications of Javier Sagüés Remón ${ }^{20}$ and Luigi Manca. ${ }^{21}$ But it is the very Augustine who gives us a first hand information of the structure of this work in the Retractationes where he writes: "Liber De agone christiano fratribus in eloquio latino ineruditis humili sermone conscriptus

13 Mt. 7, 2 as cited in Ibid.

14 Here we refer to the synod that held at the Lateran for three days beginning on 2 October 313. The Synod acquitted Caecilianus of traditio, and recognized him as lawful bishop of Carthage. On the other hand, Donatus, the principal accuser of Caecilianus is found guilty of schism on account of his re-baptising of Christians, Cf. G.G. Willis, Saint Augustine and the Donatist Controversy, SPCK, London, 1950, 7

15 Mt. 26, 52 as cited in agon. 29, 31 PL 40,306

16 Rather, it would have reduced some power to his argument of division among them!

17 Cf. G.G. Willis, 31-35

18 We know that Augustine does not either mention the armed struggle of Circumcellions, which on the other hand would have been a better tool to make contrast with the Christian combat he is dealing with! So the argument of "ex silencio" in itself is not very illuminating.

19 We will cite for example, Cf. L. Alici, 37; A.D. Fitzgerald, xliii

20 Cf. J.S. Remón, La catequesis, 171-173. Here he himself acknowledges of following generally B. Roland-Gosselin, Saint Augustins la morale chrétienne, De agone christiano, Desclée, Paris, 1947, 55ff.

21 Cf. L. Manca, 55 
est, fidei regulam continens et praecepta vivendi". ${ }^{22}$ Thus the booklet will have a bipartite structure: the first consists of chapters 1-13 (praecepta vivendi) and the second consists of chapters 14-33 (regulam fidei).

Hence the general framework would be as follows:

First Part (chapters 1-13)

In general terms, it describes the Christian combat carried out by the newly baptised Christians through faith.

It can be further divided into two sections preceded by an introduction:

Introduction: (chapters 1, 1- 4, 4)23

Here Augustine envisages the need of Christian combat and the enemy against whom the Christian must make this fight. The newly baptised Christian, therefore, should know first who this opponent is, and won against him will he be crowned with victory.

- The devil is our enemy and our Lord Jesus Christ has won the devil first; so remaining with him we too can win the devil $(1,1) ; 24$

- the way to conquer the devil is to win against our own cupidity (2, 2) 25 because

- the devil does not dwell in the heavens as some heretics affirmed (3, $3)^{26}$

- particularly the Manicheans $(4,4)^{27}$

In the chapters 5-13, Augustine particularly deals with the terms of this combat; and specially treats the nature of this combat which is interior, and not exterior.

First section (chapters 5, 5-9, 10)28

This combat, made by the Christian faithful is an internal fight and is undertaken by a total renunciation. The most easy and universal means to

22 retr. 2, 3 PL 32, 631

23 agon. PL 40, 289-293

24 Ibid. PL 40, 291

25 Ibid. PL 40, 291-292

26 Ibid. PL 40, 292

27 Ibid. PL 40, 292-293

28 Ibid. PL 40, 293-296 
this renunciation is the loving subjection to the will of God as St. Paul affirmed in 1 Cor. $9,26,27(6,6) .{ }^{29}$

Second section (chapters 10, 11-13, 14) 30

The subjection to the will of God separates us rightly from sin. But some questions remain: what means are there within our reach to discipline and purify our will? What are the spiritual weapons used in this warfare? Augustine with a perfect logic enumerates some sanctifying means:

a the humanity of Christ is Augustine's most favourite one, only whose humility can win the pride, only whose patience can win the anger, only whose charity can conquer the ungodliness and with his resurrection can cure the human weakness $(10,11-11,12), 31$

$\mathrm{b}$ the hope for the eternal life, opened by Christ $(12,13), 32$

c the faith: we should believe those truths of faith which we are not able to understand yet. This faith makes souls subject to God and leads to the observance of precepts for right living; when these are observed, our hope is made firm, charity is nurtured, and what was only believed before begins to be clearly understood $(13,14) .{ }^{33}$

Then there comes a short presentation of the baptismal symbol (chapter 13, 15) ${ }^{34}$ which closes the first part and gives way to the second.

Second Part (chapters 14, 16-33, 35)

The second part will deal exclusively with the truths of faith and the errors against it. Thus, Augustine warns the newly baptised Christians a series of errors against the faith. He lists a total of 19 errors. The dynamic of exposition is the same as the creed; it is distributed in three sections:

First section (chapters 14, 16-16, 18):35

The holy Trinity is the central theme of this section. Augustine formulates the faith of one God in three distinctive persons. These three persons are equal in perfections.

29 "Non sic pugno, quasi aerem caedens; sed castigo corpus meum, et in servitutem redigo, ne forte aliis praedicans, ipse reprobus inveniar”, Ibid. PL 40, 294

30 Ibid. PL 40, 296-299

31 Ibid. PL 40, 296-298

32 Ibid. PL 40, 298-299

33 Ibid. PL 40, 299

34 Ibid.

35 Ibid. PL 40, 299-300 
Second section (chapters 17, 19-28, 30):36

It occupies mostly the Christological truths: Jesus Christ, born of woman is the Son of God. He is true God and true man. Jesus Christ is the Redeemer, suffered without losing his divinity, died, resurrected and ascended to heaven, etc.

Third section (chapters 29, 31-32, 34):37

In this section Augustine includes the ecclesiology.

The exposition of each error is followed by a confutation. The Trinitarian part is the shortest, while the Christological has the biggest share, which in turn is followed by a shorter ecclesiological part. The book ends with an extensive exhortation to live the rule of love of God and neighbour which is the greatest means to win against the devil and his angels $(33,35) \cdot{ }^{38}$

Finally, a synthetic description of Luigi Manca beautifully summarises this structure: "The De agone christiano, though presented in two parts clearly separated themselves, it must be read following one unique thread: the "combating" dimension. Hence in the first part, if the enemy, the devil is conquered in the concupiscence of our body, in the second part, the same devil is conquered in the heresies" (tr. mine). ${ }^{39}$

\section{LITERARY STYLE}

The purpose 40 of an author dictates the choice of his literary style and it is the same Augustine who defines it as humilis sermo. ${ }^{41}$ Javier Sagües Remón who makes an exhaustive study of the literary nature of this book, in the same line, does not have any doubt to affirm the literary style of this work of Augustine as eminently catechetical. Giving a comprehensive description of the work in the catechetical framework he writes: "It deals

36 Ibid. PL 40, 300-306

37 Ibid. $P L$ 40, 306-310

38 Ibid. PL 40, 310

39 "Il De agone, pur presentandosi con due parti ben distinte fra loro, deve essere letto perseguendo un unico filo conduttore: la dimensione agonica. Se nella prima parte il nemico, il diavolo, va combattuto nella concupiscenza del nostro corpo, nella seconda parte lo stesso diavolo va combattuto nell'eresia", L. Manca, 55

40 This purpose, we will expose more in detail in the section of the scope of the work and in the $3^{\text {rd }}$ Chapter.

41 Cf. retr. 2, 3 PL 32, 631 
with an eminently pastoral and extremely simple writing. St. Augustine, following the tread of bible, justifies from the very beginning of this opuscule it's suggestive title, basing on the teaching of St. Paul, who invites the first Christians to lead a militant and combating life for the faith in Christ" (tr. mine). ${ }^{42}$ And L. Manca reiterates it: "In fact, De agone christiano can be considered as a work of catechesis, more precisely of post-baptismal catechesis of popular character, where specifically the theme of spiritual combat is developed, by which the baptised remains firm in the faith" (tr. mine). ${ }^{43}$

For Remón, the typical character of an Augustinian catechist as man of radiant joy, who with a lot of enthusiasm, always ready to inspire the love of God within the hearer is anticipated in this work. ${ }^{44}$ On the other hand, the catechist is concerned of adapting to the many varied situation of the audience avoiding all syntactic and linguistic complications. 45 Agostino Trapè also recognises the post-baptismal character of this work; further for him it is a manual of permanent or ongoing catechesis to confirm the newly baptised Christians in faith. ${ }^{46}$ Consequently, all the authors who have studied this work, ${ }^{47}$ with the exception of Scott-Craig, ${ }^{48}$ are in agreement with the catechetical ability of the author in De agone christiano.

42 "Se trata de un escrito eminentemente pastoral y extremamente sencillo. San Agustín, siguiendo el hilo de la biblia, justifica desde las primeras líneas de este pequeño opúsculo el sugestivo título de la obra, escudándose en la doctrina de san Pablo, que invita a los primeros cristianos a llevar una vida militante y batalladora por la fe de Cristo", J.S. Remón, La Catequesis, 169

43 "Il De agone, infatti, si può considerare un'opera di catechesi e più precisamente di catechesi post-battesimale a carattere popolare, dove è particolarmente sviluppato il tema della lotta spirituale, mediante la quale il battezzato rimane saldo nella fede", L. Manca, 53

44 J.S. Remón, El Educador de la fe en las obras catequéticas de San Agustín, Personalidad del catequista, 35

45 retr. 2,3 PL 32, 631; agon. 33, 35. PL 40, 310

46 Cf. A. Trapè, S. Agostino e la Catechesi: Teoria e Prassi, in Salesianum 41 (1979) $323-331$

47 Besides the authors we mention in this section, worth to mention are authors like: Cf. R.P. Russel, 311; Cf. A. Zumkeller, Der christiliche Kampf und die christiliche lebenweise, eingeleitet und erläutert, Augustinus-Verlag, Würzburg, 1961, ix-xvii; L. Cilleruelo, 476477

$48 \mathrm{He}$ considered it as "a mediocre example of Augustine's teaching technique", Cf. T.S.K. Scott Craig, On Christian Instruction, in A Companion to the Study of St. Augustine, Oxford University Press, New York, 1955, 133 
Thus, we proceed to the analysis of the catechetical outline of the work: For Remón the general schematic vision of this catechesis is the following: 49

Exordium: The Christian must fight to conquer the enemy of faith.

Instruction:

a On the Christian fight of faith

b On the way of carrying it out

c On the weapons of fight

d On the precepts

e On the truths

\section{Intimation:}

a Regarding the errors and scandals

b Regarding the theological virtues

Final exhortation: The love of Christ to conquer the devil

However, we know that in this small work we have two expositions though interdependent but sharply different, as we have above inferred from the Retractationes. And remembering this J. S. Remón proposes to us two itineraries or catechesis:

\section{First itinerary}

The sequence of this itinerary would be the following: Exordium (chapters 1, 1-4, 4)

It consists of a:

- queastio: "quomodo possumus vincere diabolum, quem non videmus?", 50

- Responsio: according to the teaching of the apostle to the Ephesians, $6,12,51$

- Propositio: the Manichean errors, $(4,4) .52$

49 J.S. Remón, La Catequesis, 173-174 (We will basically follow his framework and the translation is mine)

50 agon. 2, 2 PL 40, 291

51 “... quisquis det operam triumphare de illo in semetipso. Eos enim qui foris non oppungnant, intus vincimus, vincendo concupiscentias per quas nobis dominantur", Ibid. 2 , 2 PL 40, 292

52 Ibid. 4, 4 PL 40, 292-293 
This is followed by an:

Instruction (chapters 5, 5-10, 11),

Intimation (chapters 10, 11-11, 12);

and finally the Exhortation (chapters 12, 13-13, 14).

The terminology of combat is a particular aspect of this part of catechetical itinerary and reveals both its moral and ascetic nature. 53

In the second catechesis, Augustine follows the itinerary of "symbol":

Here it is a doctrinal exposition, which at the first instant, might look an exclusively Trinitarian one $(13,15)$. This, in the section of structure, we have divided into three categories, distinct but intrinsically united among them. But from a catechetical point of view besides these above mentioned Trinitarian, Christological and ecclesiological aspects, we can recognise the soteriological, pneumatological and eschatological components of the creed. ${ }^{54}$ The exposition follows a negative way. These truths are explained in 19 articles in a very vibrant mode with a negative phrase: "nec eos audiamus. 55 Augustine does not call the errors by name 56 but we can easily identify them.

Thus, in chapters 14, 15 and 16, we identify three Trinitarian heresies like monarchianism, ${ }^{57}$ tritheism ${ }^{58}$ and arianism ${ }^{59}$ respectively. Then comes the 12 errors of the mystery of Christ: among them the first six are exclusively Christological (chapters 17, 19-22, 24), while the following five are more soteriological (chapters 23, 25-27, 29) and the last one being pneumatological (chapter 28, 30).

53 Cf. L. Manca, 55

54 Cf. A. Trapè, 330-331

55 agon. 14, 16 PL 40,299. This phrase first appears here and is repeated till the penultimate chapter, 32,34 .

56 For Russell, Augustine would have omitted to name them to maintain the simplicity of the work, Cf. R.P. Russell, 333, f. note 1

57 It is with the name Sabellianism, after Sabellius was diffused in Egypt; among the Latins, it is called patripassianism and in modern times, is called Modalism, Cf. M. Simonetti, Monarchiani, in NDPAC, 3330-3331

58 It will be the other extreme of monarchianism. We cannot consider it a true or particular heresy but some fathers accused tritheism those theological currents that were in general anti-Sabellian, Cf. B. Studer, Triteismo, in NDPAC, 5480-5481

59 Here the subject of discussion is the Arian (Cf. M. Simonetti, Ario-Arianesimo, in NDPAC, 503-512) and Pneumatomachian (Macedonian) heresy (Cf. M. Simonetti, Pneumatomachi, in NDPAC, 4192). Against the Arians, Augustine stresses a fundamental aspect of the generation of the Son, denied by them for considering it in material sense. While Augustine understands a spiritual and eternal generation as already explained by Alexander of Alexandria in the beginning of Arian heresy. 
The Christological errors are the following as against the Catholic faith:

1. The Ebionites and its variations: ${ }^{60}$ Christ is simply a man. Truth: Christ is the Son of God incarnated for the salvation of mankind. 61

2. Docetism: ${ }^{62}$ Christ's whole body was an unreal flesh and feigned appearance ${ }^{63}$. Truth: Christ had a true human body

3. Apolinarism: ${ }^{64}$ Christ had no human mind. ${ }^{65}$ Truth: Christ had not only human soul and body but also human mind.

4. Nestorianism: ${ }^{66}$ They understood that the union of God and man was moral and not real. Truth: The union of God and man was real.

5. Christological Arianism: Christ assumed only the human body. ${ }^{67}$ Truth: the Word assumed both human body and soul.

6. Docetism and Valentine Gnosticism. ${ }^{68}$ Truth: Christ had a true body and is born of a woman. 69

The following five errors somehow negate the passion, ${ }^{70}$ the resurrection, ${ }^{71}$ the ascension, ${ }^{72}$ Christ's sitting at the right hand of the Father ${ }^{73}$ and the future judgement, ${ }^{74}$ consequently reveal the soteriological as-

60 “... qui Filium Dei Iesum Christum nihil esse aliud quam hominem dicunt, sed ita iustum, ut dignus sit appellari Filius Dei”, agon. 17, 19 PL 40, 300

61 "Credamus etiam dispensationem temporalem pro salute generis humani", Ibid.

62 Cf. B. Studer, Docetismo, in NDPAC, 1465

63 “... qui non verum hominem suscepisse dicunt Filium Dei,... sed falsam carnem et imaginem simulatam corporis humani ostendisse videntibus" and "isti totum corpus eius falsam carnem fuisse contendunt", agon. 18, 20 PL 40, 301

64 Cf. Ch. Kannengieser, Apollinarismo, in NDPAC, 417-421

65 "... sed hominem ipsum, qui temporali dispensatione susceptus est, audent dicere non habuisse hominis mentem, sed solam animam et corpus", agon. 19, 21 PL 40, 301

66 agon. 20, 22 PL 40, 301, Cf. M. Simonetti, Nestorio-Nestorianesimo, in NDPAC, $3482-3485$

67 "... qui solum corpus humanum susceptum esse dicunt a Verbo Dei”, agon.21, 23 PL 40, 302, Cf. J.S. Remón, La Catequesis, 177

68 Cf. J.S. Remón, La Catequesis, 177

69 “... nec mares fastidivit, quia marem suscepit; nec feminas, quia de femina natus est", agon. 22, 24 PL 40, 303

70 Cf. Ibid. 23, 25 PL 40, 303

71 “... qui negant tale corpus Domini resurrexisse, quale positum est in monumento", Ibid. 24, 26 PL 40, 304

72 “... qui negant ipsum corpus secum levasse in coelum Dominum nostrum”, Ibid.25, 27 PL 40,304

73 “... qui negant ad dexteram Patris sedere Filium ”, Ibid. 26, 28 PL 40, 304

74 Those who interpret crookedly "... eum qui credit in Christum, non iudicari" are wicked exegetes, Ibid.27, 29 PL 40, 305 
pect. ${ }^{75}$ On the other hand, the last pneumatological error consists in a false claim of some of the heretics of possessing the Holy Spirit. ${ }^{76}$

Among the errors that are in the ecclesiological part, the first three are strictly regarding the nature of the Church: namely, Donatism, ${ }^{77}$ Luciferianism ${ }^{78}$ and the negation of the power of the Church to pardon sins. ${ }^{79}$ The fourth one however is eschatological in nature and deals with the negation of the resurrection of the body. 80

The whole catechetical instruction ends with a final exhortation and for J. S. Remón it is very beautiful: "We are before the Christians who are just baptised and have overcome the neophytes' stage and are ready to face the daily battle against the enemies of faith. The holy bishop enjoins them to nourish with simple and authentic faith. To this wholesome nourishment- nutrimentis saluberrimis- good Christians must add the precepts of charity of Christ, summed up in the love of God and neighbour. This is the best way to triumph over - in oneself and in Christ-, the devil and his angels. This charity is kept through humility, simplicity and fear of God. Armed in this way, the Christian will achieve the final victory" (tr. mine). ${ }^{81}$

Concluding this exposition of the catechetical itinerary, we can also identify here some characteristics of this Augustinian catechesis, namely: adaptation, the theme of Christ- Church, the biblical-historical catechesis, etc.

75 Cf J.S. Remón, La Catequesis, 177

76 “... qui dicunt Spiritum sanctum, quem in Evangelio Dominus promisit discipulis, aut in Paulo apostolo venisse, aut in Montano et Priscilla, sicut Cataphryges dicunt, aut in nescio quo Manete vel Manichaeo, sicut Manichaei dicunt", agon. 28, 30 PL 40, 305

77 “... qui sanctam Ecclesiam, quae una catholica est, negant per orbem esse diffusam, sed in sola Africa, hoc est, in parte Donati pollere arbitrantur", Ibid. 29, 31 PL 40, 306

78 Ibid. 30, 32 PL 40, 307-308

79 “... qui negant Ecclesiam Dei omnia peccata posse dimittere”, Ibid. 31, 33 PL 40, 308

80 “... qui carnis resurrectionem futuram negant”, Ibid. 28, 30 PL 40, 305

81 "Estamos ante cristianos recién bautizados que han superado la etapa de los neófitos y se disponen a afrontar la lucha diaria contra los enemigos de la fe. El santo obispo los conmina a nutrir una fe sencilla y autentica. A este alimento salubérrimo- nutrimentis saluberrimis- deben añadir los buenos cristianos los preceptos de la caridad de Cristo, resumidos en el amor de Dios y del prójimo. Este es el gran medio de triunfar-en sí y en Cristo-, del diábolo y sus satélites. Este amor se mantiene por la humildad, la simplicidad y el temor de Dios. Revestido de este modo, el cristiano logrará la victoria final", J.S. Remón, La Catequesis, 178 
This adaptation $^{82}$ of the bishop of Hippo, as we have seen is well attested in his own words. ${ }^{83}$ He puts into practice, this aspect, not only in the language but also in the content and style of the work. And he has reason from the experience of human nature to justify it. ${ }^{84}$ But this is not something Augustine does in this work only, rather it seems that he is quite convinced of this that we find the same in De catechizandis rudibus 85 and in De fide et symbolo, 86 to the extent that it has become a part of his personal nature as would suggest his many letters and sermons. ${ }^{87}$

Thus Augustine presents his catechesis in an elemental way, full of practical sense. The presentation of the Christian life as combat is very appropriate in this context to the recently baptised. He finds the inspiration in this area from St. Paul who was keen to use this sort of language for the instruction of his newly formed Christian communities. ${ }^{88}$ This catechesis, together with the simple language free of rhetoric twists is sure to make an impact on this category of audience. Thus we agree with the opinion of D'Ales to call this opuscule the people's Enchiridion. ${ }^{89}$ Again this adaptation is clear from the apologetic tone of the treatise considering that these simple Christians were vulnerable to the counter-proselytising of other groups like Manicheans and Donatists..$^{90}$ The brevity of the symbol $(13,15)$ also shows that Augustine is writing in De catechizandis rudibus ${ }^{91}$ what he has already practised in De agone christiano. In this

82 Some elements of this aspect are mentioned elsewhere, which, however, for the sake of synthesis, we may repeat here!

83 Cf. retr. 2, 3 PL 32, 631

84 “... et cum parvuli sumus, maiorum cibos non appetamus...", agon. 33, 35 PL 40, 309-310

85 Cf. cat. rud., 7, 11-8, 12 PL 40, 317-319

86 "...in quo de rebus ipsis ita disseritur, ut tamen non fiat verborum illa contextio, quae tenenda memoriter competentibus traditur", retr. 1, 17 PL 32, 612

87 For a detailed treatment of the point, see Cf. A. D'Ales, $133 \mathrm{ff}$.

88 We shall cite only some of them as used by Augustine in this work: 1 Cor. 9, 26-27 (Cf. agon. 1, 1 PL, 40, 294); 2 Tim. 4, 7-8, (Cf. agon. 1, 1 PL, 40, 291); Eph. 2, 2 (Cf. agon. 1, 1 PL, 40, 294); Eph. 6, 12 (Cf. agon. 3, 3 PL, 40, 292)

89 «Tandis que le De catechizandis oriente l'activité des ministres de l'Evangile vers la pénétration des masses pa ennes, le De agone christiano amorce un travail en profondeur. Le pasteur d' âmes s'y montre en contact avec ses ouailles les moins cultivées, se faisant tout à tous. On l'a très bien appelé l' Enchiridion du peuple, car il unit à une catéchèse élémentaire, un entrainement efficace vers les vertus essentielles du chrétien», A. D'Ales, 144

90 Cf. agon. 4, 4 PL, 40, 292-293

91 In fact, Augustine is advising Diogracias the brevity of exposition, Cf. cat. rud. 7,11 PL 40, 317-318 
sense, he is perfectly adapting to the audience: pro capacitate ac viribus audientis, proque ipsius temporis modulo. ${ }^{92}$

Another important aspect of this catechesis is Augustine's presentation of Christ in close union with the Church and it is the most extensive part of the book (chapters 17, 19-33, 35). ${ }^{93}$ But the most highlighting element is his biblical-historical method. To support his catechetical teaching Augustine abundantly uses the sacred scriptures. J. S. Remón is quite convinced of this when he says: "The iter biblicum is present, evidently or underlined, in all the explanation and pages of this booklet" (tr. mine). ${ }^{94} \mathrm{He}$ gives a complete list of biblical citations in the book in order to prove this. ${ }^{95}$ This biblical catechesis is joined with the history of the Church together with heresies. And once again it would foreshadow what is said in De catechizandis rudibus. 96

There are other aspects of this catechesis which are worth mentioning. For example, we recall the simplicity of the exposition of the symbol. There is no complex theological exposition; not even the names of the errors treated, are mentioned. However, there is a clear definition and a brief confutation of the errors contrary to the symbol. Augustine's marking of each error with the "nec eos audiamus" add to the clear division between them. ${ }^{97}$ Finally, Augustine's call to charity is something to be noted as well. ${ }^{98}$ For Augustine all the catechetical instruction is directed towards love and should enkindle the love. Charity is the centre of catechesis and essential remedy to triumph for Christ. ${ }^{99}$ Thus it is very true the observation of A. Trapè who affirmed "all his (Augustine's) psychological

92 Ibid.

93 Cf. J.S. Remón, La Catequesis, 180-181. We limit here to this extend as our purpose is only to show the catechetical nature and not an exhaustive study of all the catechetical elements of the work!

94 "El iter biblicum está presente, expresa o veladamente, en todas las explicaciones y páginas de ese opúsculo", Ibid., 181

95 Cf. Ibid. pp. 181-182

96 "Narratio plena est, cum quisque primo catechizatur ab eo quod scriptum est: In principio fecit Deus caelum et terram, usque ad praesentia tempora Ecclesiae", cat. rud., 3, 5 PL 40,313

97 Cf. A. Trapè, 331

98 “... et nutritur caritas, et lucere íncipit quod antea tantummodo credebatur", agon.13, 14 PL 40, 299 and "Quia perfecta caritas nec cupiditatem habet saeculi, nec timorem saeculi. Per quas duas ianuas intrat et regnat inimicus, qui primo Dei timore, deinde caritate pellendus est", agon. 33, 35 PL 40, 310

99 Cf. J.S. Remón, La Catequesis, 186 
intuitions and didactical observations has only one common denominator: the charity" (tr. mine). ${ }^{100}$

Almost all of these characteristics of catechesis are found articulated, particularly in the first part of De catechizandis rudibus $(3,5-14,22)$, the manual of catechesis came to us from Augustine himself.101 Thus we can rightly assume that what Augustine has been practising in his life as a catechist since his ordination (year 391) ${ }^{102}$ particularly in moments of $D e$ fide et symbolo (year 393 )103 and De agone christiano (year 396), finds its synthesis in his articulation of the methods of catechesis which he made upon request of the deacon of Carthage, Deogratias (year 400). ${ }^{104}$ This, on the other side, helps us to affirm retrospectively once again the true catechetical nature of De agone christiano.

\section{SCOPE AND ADDRESSEE}

We have put together these two elements in the sub-title not without a specific reason. It seems that the scope and the addressee of this opuscule are somehow reciprocally related. It can be inferred from the initial words of Retractationes on this book: "Liber De agone christiano fratribus in eloquio latino ineruditis humili sermone conscriptus est". ${ }^{105}$ But as pointed out before in the case of Ad Simplicianum (section 1. above) here too we have to keep in mind that this assertion in Retractationes was not written at the time of composition of the work (396), rather it was what Augustine had remembered of the work when (years 426/27) he had revised the same. ${ }^{106}$ However, this fact in no way contradicts the claim rather reinforces it further because at the end of the work, Augustine through his final exhortation makes it clear that this small book in one volume was written for those neo-Christians, "parvuli sumus" who have

100 Cf. A. Trapè, 328

101 Cf. P. Siniscalco, Introduzione, in Prima Catechesi Cristiana, NBA VII/2, Città Nuova Editrice, Roma, 141-144. However, we remember that they are different in their catechetical addressees that is, De catechizandis rudibus to the pagans while De agone christiano to the neo-Christians!

102 Cf. P. Brown, 64

103 Cf. A.D. Fitzgerald, xlv

104 Cf. A. Trapè, 323-324

105 retr. 2, 3 PL 32, 631. Here, for example, we see how Augustine thinking of his "fratribus in eloquio latino ineruditis", decides to write in "humili sermone".

106 Cf. A.D. Fitzgerald, xlviii 
just received the faith. ${ }^{107}$ And these newly baptised could perfectly be fit into the fratribus in eloquio latino ineruditis. The brevity of the explanation of the symbol of faith $(13,15)$, according to Luigi Manca shows that the addressees were already Christians. ${ }^{108}$ This could also be interpreted by way of a catechetical tactic, as we have seen above in the previous section. To these fellow Christians, Augustine wants to offer "the mode and means" of attaining "corona victoriae" or in other words, to reach heaven. ${ }^{109}$ The whole of this process is considered as a combat or struggle against the devil, hence the name "De agone christiano"110 following the same spirit of St. Paul.111

Then in the first part (chapters 1-13) we see that the treatment, in its entirety is dedicated to define and delineate the nature of this combat, but the key to this explanation is distancing and refuting the Manichean heretical ideas. 112 The second part (chapters 14-33) is completely dedicated to a particular exhortation, that is, an exhortation to avoid the different heretical ideas, particularly highlighting the Donatists and Luciferians. 113

Thus from what we have exposed above we can identify two keys to explore the scope and addressee of this work: first, the fact of being written in simple Latin (linguistic key), second, its exposition of various heresies (anti-heretical key). Following this framework of language and heresies we will, now, investigate into the addressee of De agone christiano so as to illuminate ourselves regarding its scope.

A search of this kind to the addressee of De agone christiano will inevitably bring our attention to the socio-cultural and demographic map or constitution of the people of Hippo Regius in the whole panorama of

107 Cf. agon. 33, 35, PL 40, 310

108 Cf. L. Manca, 56

109 Cf. agon. 1, 1 PL 40, 289-290; agon. 33, 35, PL, 40, 310

110 It is the original title of the work given by Augustine himself, Cf. retr. 2, 3 PL 32, 631

111 Cf. "Opus perfeci, cursum consummavi, fidem servavi; iam superesti mihi corona iustitiae", 2 Tim. 4, 7-8, cited at the very beginning of the work, agon. 1, 1 PL 40, 291

112 Among the many instances, we have one clear example in agon. 4, 4 PL 40, 293

113 The only errors the bishop of Hippo mentions by name in this work, at the moment of refuting are Manicheans, Donatists and Luciferians; But without doubt we are sure that he knows most of them by name [Cf. agon. 30, 32 (the Arians are here mentioned just in passing); Cf. De hearesibus] but here it seems that he might have omitted to name others so as to keep the simple nature of the work and named only those who are directly present in the African context. 
Roman north Africa. Thanks to various studies in this level114 that today we have a better understanding of this background in which Augustine lived, worked and wrote the immense legacy of his literature, be it cultural or linguistic, be it social or demographic, etc.

The possibility that Augustine could have an indirect Berber origin or his formation in Punic culture ${ }^{115}$ are matters that need further study and do not enter directly into our scope. However, the existence of Punic culture and language still in the $4^{\text {th }}$ and $5^{\text {th }}$ century of north Africa is far from any hypothesis and was a crude reality of Augustine's day-to-day pastoral life ${ }^{116}$ and his controversial literary life. ${ }^{117}$ We have to search in this background the addressee and consequently the scope of De agone christiano.

Augustine wrote:" Liber De agone christiano fratribus in eloquio latino ineruditis humili sermone conscriptus est". But, who were these brothers whose Latin formation was insufficient or quite poor to understand an elegant Latin literature? Here we have to keep in mind that common to many of the military invasions, the Roman occupation of north Africa at any rate did not completely annihilate the native culture. ${ }^{118}$ Moreover, Romans were neither interested much in foreign languages, nor were they hostile to them!119 So the administrative Latin should have remained among the Roman immigrants and the then north African upper class who accepted and accommodated themselves to the Roman domination as a part of their tactic and social beneficence. To this we have to add also the upper-middle-class (the family of Augustine probably belonged to this group $)^{120}$ who were the administrative aides of the Romans in small towns. ${ }^{121}$ But the rest of the population who would have remained in the villages and interior parts might have continued with the

114 We shall mention only a few like: F.van der Meer; J.E. Merdinger; F. Decret; M. Ellígsen; W.H.C. Frend; P. Brown etc.

115 Cf. ep. 17, 2 CSEL 34, 1, 39; F. Vattioni, Sant'Agostino e la Civiltà punica, in Augustinianum 8 (1968) 435; K. Power, Family, Relatives, in Augustine through the Ages, 353

116 Cf. ep. 84 CSEL 34, 2, 392-393

117 Cf. ep. 66 CSEL 34, 2, 235-236

118 Cf. J.E. Merdinger, Rome \& the African Church in the Time of Augustine, Yale University Press, New Haven and London, 1997, 69

119 Cf. F. Vattioni, 456

120 Cf. conf. II, 3, 5 PL 32, 677

121 Cf. F. Vattioni, 436; W.H.C. Frend, A note on the Berber Background in the Life of Augustine, in JThs 43 (1942) 190 
culture and language (also gods) of their ancestors. ${ }^{122}$ It is also important to note that they might be hardly in any position to pay for the Latin formation which would be only available in urban or large cities. ${ }^{123}$ It is all the more true that there was no possibility to learn local languages in those cities either. ${ }^{124}$ Besides the Romanised elite class, though knowing the local language, also practised Latin at home, which eventually left their children with no chance to learn them.125 This, on the other hand would explain why Augustine had no substantial knowledge of his African language. ${ }^{126}$

However, it seems that at Hippo Regius, at least in the town area, Augustine's audience spoke and understood fairly the spoken Latin, although many of them would not know reading and writing. ${ }^{127}$ Then, that was not altogether bad for an ordinary man because in the antiquity reading and writing were considered as professional skills and were not part of common formation as today. Besides, written works were thought to be read aloud and were "oral" in their composition and intention. Hence, it was customary that a literate person might read and others would listen to it. 128

This being the case of language formation, now let us look into the demographic distribution of north Africa to see who formed this fratribus in eloquio latino ineruditis. From Augustine himself, we know that Christian Africa was more Donatist than Catholic. ${ }^{129}$ But Hippo being a port city and its geographical location had given a better position to the

122 Cf. J.E. Merdinger, 69; F. Vattioni, 461

123 We know that after Augustine's preliminary education, his father made great sacrifices to send him for higher studies, Cf. conf. II, 3, 5 PL 32, 677; and later on the father's death, it is Monica who supported him economically, Cf. conf. III, 4, 7 PL 32, 685

124 Cf. F. Vattioni, 446

125 Cf. K. Power, 353; M. Ellígsen, The Richness of Augustine, his contextual \& pastoral theology, WJK Press, Louisville, 2005, 8; Cf. conf. I, 14, 23 PL 32, 671

126 Cf. ep. 66, 2 CSEL 34, 2, 236; ep. 84, 2 CSEL 34, 2, 393; F. Vattioni, 446

127 Cf. F.van der Meer, Augustine the Bishop, the life and work of a father of the Church, Sheed and Ward, London, 1962,175,140 and 144. (From these pages it is clear that Augustine's liturgical congregation followed with enthusiasm the preaching of the bishop and they showed their appreciation too, which at times burst into applause).

128 Cf. T.F. Martin, Reading the Works of St. Augustine, in Elements of an Augustinian Formation, Pubblicazioni Agostiniane, Roma 2001, 40-41

129 Cf. F.van der Meer, 29; W.H.C. Frend, The family of Augustine: a microcosm of religious change in north Africa, in Atti del Congresso internazionale su S. Agostino nel XVI centenario della conversione Vol. 1, Institutum Patristicum Augustinianum, Roma 1987, 150 
Catholics; however still it was more of a Donatist stronghold. Hippo was home to many pagans, Manicheans and Jews as well. ${ }^{130}$ Its seaport position and vicinity to Carthage- another port and the metropolitan city- on the other hand, would give much more contact to all the heresies because persecutions always dispersed the heretics. "Moreover, it is likely that because of its strong influence, which wore down the Catholic Church's resistance, Donatism indirectly encouraged other heresies to take root in Africa". ${ }^{131}$ Adding to these, was the fact that in Hippo, as the whole of north Africa, paganism and their customs still remained; the Manicheans were also an influential group. ${ }^{132}$ All these elements were conducive to an easy proselytising activity between the different groups in an effort to strengthen their own group. In fact Augustine himself gives hint of this at the end of the introductory chapters. ${ }^{133}$ Normally, ordinary people were the primary target as they were easily convinced or forced. Sometimes groups of people were converted ${ }^{134}$ and the fact that Catholics and Donatists had the same faith would make this passage from one to another easier or at times forced. ${ }^{135}$ Finally, there were instances of switching sides for fear of disciplinary actions. ${ }^{136}$

This would draw our attention to the observations that considered the Donatists as a nationalist movement against the Roman State ${ }^{137}$ and as being completely Punic. ${ }^{138}$ There are scholars who do not accept it fully or keep still some doubts regarding its sustainability. ${ }^{139}$ We also know that the Donatist bishops themselves once asked the Roman authorities to suppress the Circumcellions (the armed hand of Donatists) between 340-345.140 But we neither ignore the facts that the Circum-

130 Cf. J.E. Merdinger, 69

131 F. Decret, Early Christianity, 143

132 Cf. Ibid., 144-158

133 Cf. agon. 4, 4 PL 40, 293

134 Cf. F.van der Meer, $26 f f$.

135 Cf. ep. 66 CSEL 34, 2, 235-236

136 Cf. ep. 108, 19. CSEL 34, 2, 632-633. Besides, we also remember how Augustine himself drew his friends to Manichaeism, Cf. conf. IV, 1, 1 PL 32, 693 and IV, 4, 7 PL 32, 696

137 Cf. W.H.C. Frend, The Donatist Church: a movement of protest in Roman north Africa, Claredon Press, Oxford, 1952; F. Vattioni, 436

138 Cf. M. Ellígsen, 9

139 Cf. F. Decret, Early Christianity, 139

$140 \mathrm{Cf}$. Ibid., 108. However, later when in 347, the imperial authority began to take disciplinary measures against Donatists, protecting the Catholic Church, they sought the help of the Circumcellions, Cf. Ibid., 112 
cellions knew only Punic and the Donatist bishop Macrobius when wanted to chastise them, speak through an interpreter in Punic. ${ }^{141}$ Still, this does not mean either that among the Catholics were less or no Punic speaking people at all. ${ }^{142}$ Or among the Donatists were there no Romanised people. ${ }^{143}$ So a reasonable understanding would be that the Donatists, at least among their followers had a predominance the people of this lower stratum ${ }^{144}$ or the Donatists projected themselves as champions of these people, when they were subjected to the imperial legislation, exploiting the anti-Roman emotion of the Punic-culture people especially the Circumcellions!

Augustine fighting against the different heretical fractions and aware of their influence among the people of lower strata of life, could not ignore this considerable amount of people. ${ }^{145}$ Moreover, at the time of his writing this small work, a good number of them formed part of the Catholic Church. ${ }^{146}$ So he cannot write to them in an elegant Latin which most of them would not have any chance to understand at all. Besides, the precise time of the composition of this work soon after his episcopal ordination (year 395) shows his preferential pastoral concern for the instruction of this part of the folk and thus justifies his writing in simple language.

Besides Luigi Manca, in his introduction to this work observed that in the treatment of heresies: Trinitarian, Christological and ecclesiological, the latter ones had received more attention than the three Trinitarian

141 Cf. ep. 108, 14 CSEL 34, 2, 628

142 Cf. ep. 84, 2 CSEL 34, 2, 393. In this letter, Augustine justify himself to bishop Novatus, his holding back the deacon Lucillus for Hippo in order to minister the Punic speaking faithful of his own diocese. At the same time he points out that Punic is common in Sitifis, the bishopric of Novatus thus implicitly affirms that it was a Catholic diocese which was basically Punic in language.

143 Cf. ep. 108, 14 CSEL 34, 2, 628. Here in fact it is quite clear that Macrobius does not know Punic (therefore Latin-speaking) which makes him seek the help of an interpreter to speak to the Circumcellions who understands only Punic; see also Cf. ep. 66, 2 CSEL 34, 2, 236

144 Cf. F. Vattioni, 445

145 Here it is better to understand the Punic culture as something non-Roman, without entering into whether the people were Berber or Phoenician origin but simply in the sense of African, Cf. M. Ellígsen, 9

146 Cf. F.van der Meer, 132. It can be inferred from the citation of the retr. 2, 3 we saw above. The continuous imperial laws against pagan religion also would have some role to bring a considerable amount of commoners to the Catholic fold, Cf. P. Siniscalco, 138-139. 
heresies; ${ }^{147}$ this, in one way, shall guide us to Augustine's concerns about the Manicheans and Donatists with whom he had fought over Christological and ecclesiological errors respectively. By mentioning these heresies by name, Augustine might have a scope to warm his people about these heresies as a need of the time, avoiding any chance of them being easily become prey to the proselytising of these adversarial groups as we have indicated above.

Thus summarising, we can reasonably assume that the scope of this work is to give a catechetical instruction to Augustine's faithful in Hippo on (De) agone christiano which is proper to the "Catholica". ${ }^{148}$ Of course Augustine had written many works against the Manicheans in his first years of ecclesiastical responsibility and successfully debated their local leader who was forced to leave the city. ${ }^{149}$ This recent activity is reflected strongly in this book especially in the first part where the principal point of reference is the Manichean heresy. Moreover, he is convinced that it would be better to have an extra strength in the knowledge of other heresies; and from this the second part of the exposition of errors proceeds as a means of preventing the Manichean (potentially others too) proselytising. ${ }^{150}$ In this ambience, the Donatists and Luciferians are also mentioned at length being their contextual relevance in Hippo, in the general scenario of the heretics. Hence, the direct addressee of this work would be the Catholic Christians of humble cultural formation both in language and faith, that is, especially the newly baptised under the pastoral care of the saint of Hippo and the scope of the work would be their faith formation without pointing out a particular ethnic group as D'Ales did. ${ }^{151}$ Consequently, the work would constitute in general terms a simple manual of instruction in the Christian rule of faith. ${ }^{152}$

But this should not blind our eyes to other potential or indirect addressees and hence a related scope. Because, we see that Augustine

147 Cf. L. Manca, 55

148 Cf. agon. 4, 4 PL 40, 293

149 Cf. J.E. Merdinger, 69; Cf. S.R. Hopper, The Anti-Manichean Writings, in A companion to the study of St. Augustine, Oxford University Press, New York, 1955, 157

150 “... qui autem fidem catholicam ben didicit, et bonis moribus et vera pietate munitus est, quamvis eorum haeresim nesciat, respondet illis tamen. Nec enim decipi potest, quiiam novit quid pertineat ad christianam fidem, quae catholica dicitur, per orbem terrarum sparsa...", agon. 4, 4 PL 40, 293

151 Cf. L. Manca, 56-57

152 Cf. N.J. Torchia, De agone christiano, in Augustine through the Ages, 15-16 
feels himself African and all that is African and Punic, he treats with respect. ${ }^{153}$ Besides, he is very careful not to offend anybody in this regard, though in doctrinal and other matters he had to disagree with them. ${ }^{154}$ This fact, considered together with other indications from Augustine's life would help us to understand his tremendous desire to reach to all his African fellow citizens. For example, he had collected all his works in a library and let others to use or copy it; 155 he was anxious of the formation of both lay and clergy, including bishops ${ }^{156}$ and wrote and travelled ${ }^{157}$ for this purpose. He dialogued, tolerated ${ }^{158}$ and even made public disputes with the heretics. ${ }^{159}$ Considering all this together, it will not be an exaggeration or a mere hypothesis if we say that when the bishop of Hippo wrote De agone christiano, he had in mind all the Christians, be it Catholic, Donatist or Luciferians, ${ }^{160}$ be it Manichean or any other denomination (including the heretics); be it clergy in its various grades or lay ${ }^{161}$ who could read the work or listen to a reader or translator 162 and would come to the true knowledge of Christian combat, liberating themselves of errors ${ }^{163}$ to form one flock in Christ $^{164}$ because

153 Cf. F. Vattioni, 466-467

154 Cf. ep. 17 CSEL 34, 1, 39-44 (Augustine's reply to Maximus a pagan, invokes their common African origin); Cf. ep. 52, CSEL 34, 2, 149-151 (Letter to bishop Severinus, Augustine's relative but Donatist).

155 Cf. Possidius, The Life of St. Augustine, XVIII, 31, Augustinian Press, Villanova, 1988.

156 Cf. F. Decret, Early Christianity, 183

157 Cf. G.G. Willis, 40-41

158 Augustine's recamendation to Secundus to read his books on Free Will, which are found with Paulinus of Nola is a good example of this attitude, Cf. c. Sec. 11, in The Manichean Debate, New City Press, New York, 2006, 374

159 Cf. S.R. Hopper, 157

160 In chapters 29-30 Augustine is very precise by just mentioning only the question of division and rebaptising (seen also above, ep. 66; ep. 108) which is helpful towards conveying to the commoners (also among the Donatist section) the concrete elements for their simple understanding.

161 Here we remember what we said above that the majority of the Donatist followers knew only Punic or little Latin.

162 Cf. ep. 84; CSEL 34, 2, 392-393; ep. 66 CSEL 34, 2, 235-236. See also Cf. T.F. Martin, 40-41

163 Augustine's exposition of the symbol of faith in negative catechesis could suggest this; and the particular mention by name only Donatists, Luciferians and Manicheans would strengthen this argument!

164 Cf. Jn. 17, 21 
they are all brothers to him although some were false. ${ }^{165}$ Augustine's strong affirmation, "Est enim magna virtus pietatis, pax et unitas"166 would further seal this argument.

165 In this regard we would cite the following passages to show that Augustine's tone is of more invitation though there is some polemic; "Sine dubio ista exsecrarentur homines, et eos sine dilatione relinquerent, si Christum quaererent...", agon. 29, 31 PL 40, 307; "Nam et amputatos ramos denuo posse inseri, si non permanserit in incredulitate, apertissime Apostolus docet", agon. 30, 32 PL 40, 307-308. And Augustine's motivation is correction considering the heretics as brothers, Cf. L. Manca, 65, f. note 71 .

166 agon. 30, 32, PL 40, 307-308. The whole chapter is a call for unity. Augustine, invoking the example of Peter who was restored to faith after his fall, argues that Church being the symbol of Peter should forgive others who fall, and accept them. He invokes also the example of Church's mercy with regard to those who had fallen during the Arian persecution. 